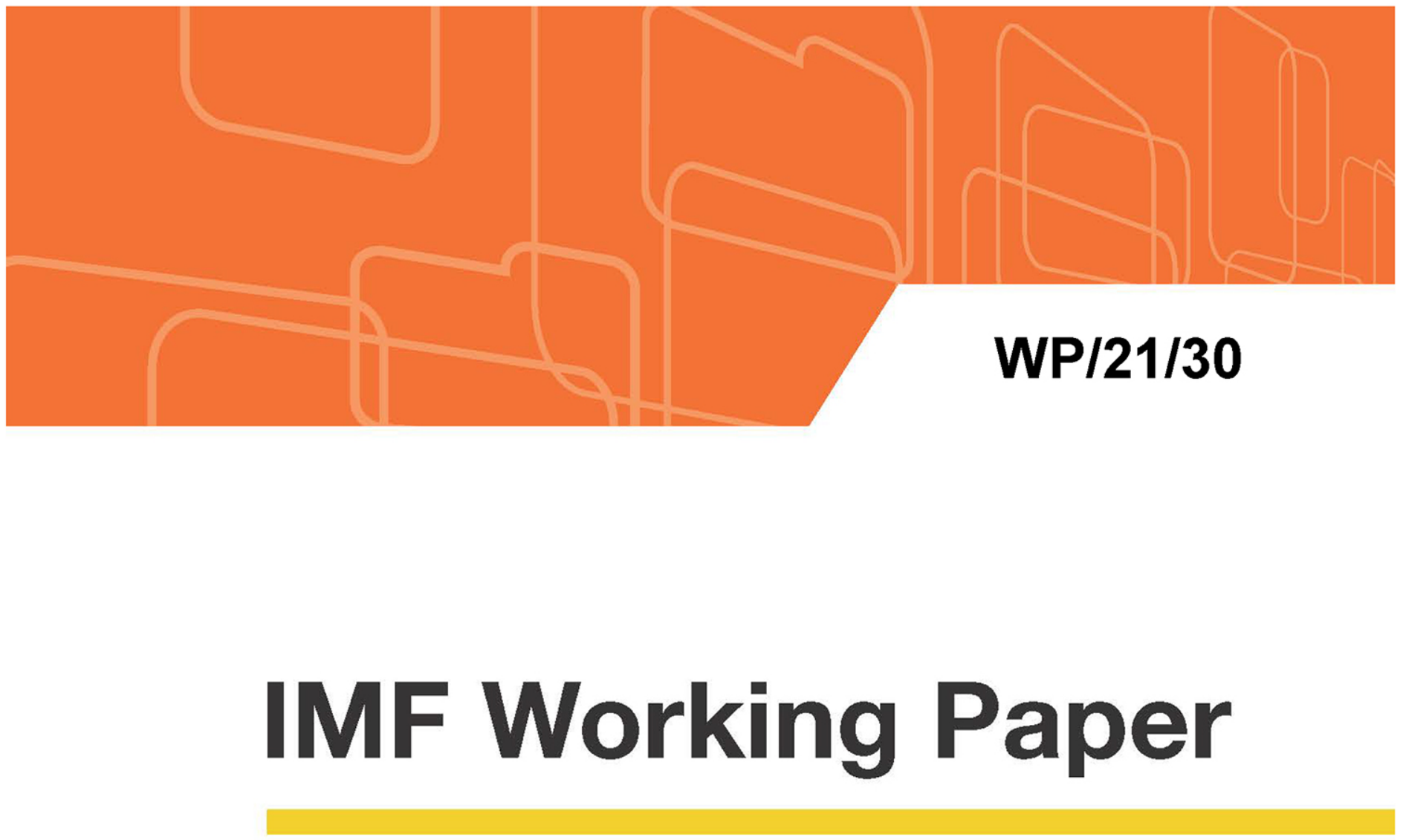

\title{
Macro-Fiscal Management Practices in Eastern and Southern Africa
}

by Bryn Battersby and lan Lienert

IMF Working Papers describe research in progress by the author(s) and are published to elicit comments and to encourage debate. The views expressed in IMF Working Papers are those of the author(s) and do not necessarily represent the views of the IMF, its Executive Board, or IMF management.

I N T E R N A T I O N A L M O N E T A R Y F U N D 


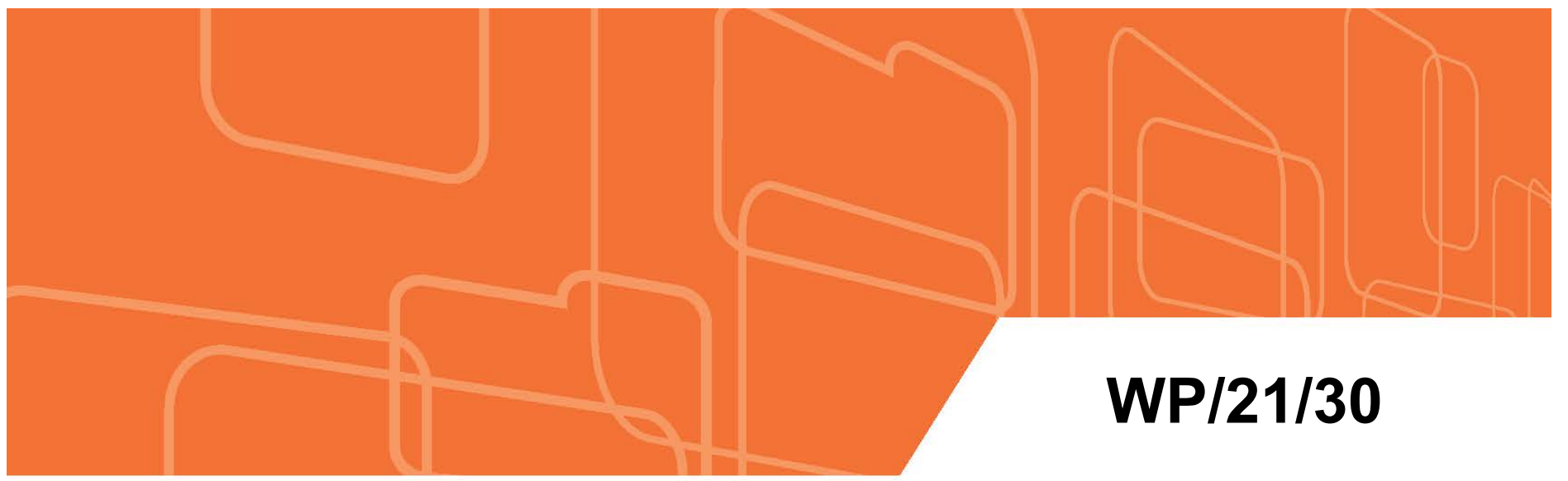

\section{IMF Working Paper}

\section{Macro-Fiscal Management Practices in Eastern and Southern Africa}

by Bryn Battersby and lan Lienert

IMF Working Papers describe research in progress by the author(s) and are published to elicit comments and to encourage debate. The views expressed in IMF Working Papers are those of the author(s) and do not necessarily represent the views of the IMF, its Executive Board, or IMF management.

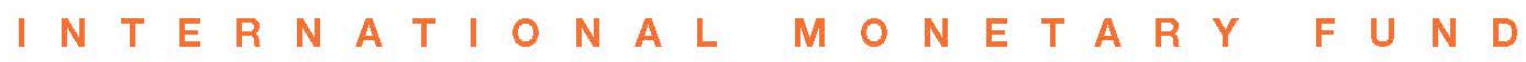




\title{
IMF Working Paper
}

Fiscal Affairs Department

\section{Macro-Fiscal Management Practices in Eastern and Southern Africa \\ Prepared by Bryn Battersby and Ian Lienert}

Authorized for distribution by Carolina Rentería

February 2021

IMF Working Papers describe research in progress by the author(s) and are published to elicit comments and to encourage debate. The views expressed in IMF Working Papers are those of the author(s) and do not necessarily represent the views of the IMF, its Executive Board, or IMF management.

\begin{abstract}
This paper examines the institutional arrangements of the macro-fiscal function in 16 African countries. Most ministries of finance (MoFs) have established a macro-fiscal department or unit, but their functions, size, structure and outputs vary considerably. Based on a survey, we present data on staff size, functional scope and the forecasting performance of macro-fiscal departments and identify common challenges in the countries reviewed. Some MoFs perform many macro-fiscal functions, but actions of various kinds are needed to strengthen their macro-fiscal departments. This paper provides some guidance for policy-makers in the region for enhancing the quality and scope of macro-fiscal outputs.
\end{abstract}

JEL Classification Numbers: H30, H50, H60, H61, H62, H63, H68, K00, K39

Keywords: macro-fiscal, macroeconomic, fiscal, function, medium-term, annual, forecasts, projections, policy analysis, fiscal strategy, ministry of finance, organizational

Authors' E-Mail Addresses: bbattersby@imf.org; lienert.ian@gmail.com 
Table of Contents

ABSTRACT

INTRODUCTION $\underline{5}$

II. THE KEY COMPONENTS AND OUTPUTS OF THE MACRO-FISCAL FUNCTION $\underline{6}$

III. INSTITUTIONAL ARRANGEMENTS FOR THE MACRO-FISCAL FUNCTION OUTSIDE AFRICA $\underline{8}$

IV. ORGANIZATIONAL ARRANGEMENTS FOR THE MACRO-FISCAL FUNCTION IN 16 AFRICAN COUNTRIES

V. LEGAL FRAMEWORK $\underline{14}$

VI. MACROECONOMIC AND FISCAL FORECASTING: TOOLS AND PERFORMANCE $\underline{16}$

VII. OUTPUTS OF MACRO-FISCAL DEPARTMENTS $\underline{20}$

VIII. CHALLENGES AND POLICY ORIENTATIONS FOR STRENGTHENING THE MACRO-FISCAL FUNCTION $\underline{23}$

IX. SUMMARY AND CONCLUSIONS 27

BIBLIOGRAPHY $\underline{29}$

\section{BOX}

1. Key Macro-Fiscal Outputs

\section{FIGURES}

1. Distribution of Macro-Fiscal Functions within MoFs 10

2. The number of Staff and Macro-Fiscal sub-Functions of MFDs in 12 Countries $\frac{11}{12}$

3. Proportion of Total MoF Staff in MFD 12

4. Rate of Staff Turnover in selected MFDs 12

5. Salary of MFD Department Heads Compared to Other MoF Senior Executives 14

6. Average Error of Non-Grants Revenue Forecasts 19

7. Average Absolute Error of Non-Grants Revenue Forecasts $\underline{19}$

8. Average Error of Nominal GDP Growth Forecasts $\underline{19}$

9. Average Absolute Error of Nominal GDP Growth Forecasts

10. Average Error of Real GDP Growth Forecasts 20

11. Average Absolute Error of Medium-Term Real GDP Growth Forecasts $\underline{20}$

12. Budget Documents Prepared and Published in 16 Countries $\underline{21}$

13. Challenges in Performing Macro-Fiscal Functions in East and Southern African MFDs

24




\section{TABLES}

1. Organizational Arrangements for Macro-Fiscal Functions

2. Legal Requirements for MTFFs in Four African Countries

3. Production and Publication of Forecasts by Country

4. Production and Publication of an Extended Set of Macro-Fiscal Documents

5. Regressions of Forecast Performance Against MFD Characteristics

\section{ANNEXES}

1. Names of the Macro-Fiscal "Departments" of MOFs $\underline{31}$

2. Fiscal Rules and Fiscal Frameworks 32

3. Medium-Term Forecast Performance Analysis 3.

4. Notes on the Database Prepared from this Paper $\frac{37}{38}$

5. Kenya's Statement of Fiscal Risks 


\section{INTRODUCTION ${ }^{1}$}

Institutional arrangements of Ministries of Finance (MoFs) ${ }^{2}$ can impact on the effectiveness of achieving macro-fiscal objectives and longer-term fiscal stability. ${ }^{3}$ In this context, many African MoFs have extended the time frame for fiscal planning beyond the annual budget year. Mediumterm fiscal frameworks (MTFFs), targets and strategies are prepared in most African countries, with mixed results. In several countries, MTFFs are accompanied by fiscal rules (CABRI, 2015a). Also, some African countries are attempting to implement performance-oriented budgeting (Lienert, 2013).

Such reforms require MoFs to change their role from controlling detailed budgets to providing a strategic approach to budget management (Schick, 2001), so as to ensure that fiscal policies and priorities are consistent with a MTFF. ${ }^{4}$ This paper focuses on the internal structures of selected African MoFs as they pursue new approaches to fiscal management.

In recent years, several African countries have reorganized their MoFs, including in some cases to strengthen their macro-fiscal management functions. Several countries have established a macro-fiscal department (MFD) or unit inside the MoF, while others have located the MFD in a ministry of economy or planning. This paper takes a view on the preferred arrangement for the location of the MFD and reviews the wide variance in the size of MFDs in a 16-country sample of eastern and southern African MoFs. ${ }^{5}$

To the authors' knowledge, there are no cross-country studies on the performance of the macrofiscal function in the MoFs of African countries. CABRI (2015b) examined whether MoF functions, at each stage of the budget cycle, were performed by the ministry of finance, or by other ministries and agencies. This paper, in contrast, focusses narrowly on one specific role of a MoF: the macro-fiscal function. As such, it aims to partly fill the knowledge gap, by drawing on the results of a survey of the macro-fiscal function of the 16 countries and an analysis of their macrofiscal forecasts.

\footnotetext{
1 The authors are most grateful to Hervé Joly, Carolina Rentería, Richard Allen, Isabell Adenauer, Stephen Ayerst, Laura Doherty, Lesley Fisher, Jason Harris, Sybi Hida, Roland Kpodar, Jean-Pierre Nguenang, Fazeer Rahim, Eivind Tandberg and some IMF African Department economists who provided helpful comments on earlier drafts.

2 The term MoF is used generically, to indicate the functional responsibilities of a "Ministry of Finance". In some countries, two or more ministries and/or central government agencies perform MoF functions.

${ }^{3}$ Allen et al. (2015) describes the challenges facing developing countries in strengthening their MoFs.

${ }^{4}$ For simplicity, we have used the term MTFF throughout, rather than the term medium-term budget framework (MTBF). For a discussion of the differences between a MTFF and MTBF, see Allen et al. (2017).

${ }^{5}$ The 16 countries were selected because all were invited to an IMF-sponsored regional workshop on the macrofiscal function, held in Dar es Salaam in January 2018. The IMF's two technical assistance centers (AFRITAC East and AFRITAC South) invited participants from the MoFs to make presentations and verify data, for which the authors are most grateful. Any remaining factual errors are the authors' responsibility.
} 
We have three main objectives:

- $\quad$ Review institutional arrangements for performing the macro-fiscal function in the MoFs of the 16 African countries listed in Annex $1 .{ }^{6}$

- $\quad$ Assess the strengths and weaknesses in performing macro-fiscal functions in these countries.

- $\quad$ Discuss the main challenges and possible policy solutions for strengthening macro-fiscal management in eastern and southern African MoFs.

The paper is structured as follows. Section II reviews the key components and outputs of the macro-fiscal function. Sections III and IV examine the institutional and organizational arrangements for the macro-fiscal function outside Africa and in the 16 African countries. Section $V$ and Annex 2 examine the legal framework, fiscal rules and medium-term budget targets for the 16 countries. Sections VI and VII review macro-fiscal forecasting performance and the outputs of MFDs of the 16 countries. Section VIII examines the challenges identified by the MFDs and discusses options for strengthening their performance. We conclude in Section IX. Three other annexes support the analysis.

\section{THE KEY COMPONENTS AND OUTPUTS OF THE MACRO-FISCAL FUNCTION}

A principal task of any MFD is to prepare a MTFF, which lays out medium-term fiscal projections, the fiscal policies needed to achieve medium-term fiscal objectives, and an analysis of fiscal risks. To constrain fiscal aggregates, some countries also adopt fiscal rules, compliance with which is an integral component of the MTFF.

Three main macro-fiscal functions are identified:

- Macroeconomic and fiscal forecasting, which may include debt sustainability analysis (DSA).

- $\quad$ Policy analysis (including macroeconomic, fiscal, and tax policy).

- $\quad$ Fiscal risk analysis.

Within these three functions, we identify 10 sub-functions often undertaken by MFDs. ${ }^{7}$ These are:

1. Macroeconomic forecasting. This includes the preparation of annual and medium-term forecasts for macroeconomic variables that are central to the budget and fiscal policymaking processes. The most important macroeconomic forecasts are typically those for GDP

\footnotetext{
${ }^{6}$ The United Republic of Tanzania is composed of mainland Tanzania and Zanzibar. Since Zanzibar has separate governance arrangements (including a President and a Parliament) and a separate public financial management system, in this paper, mainland Tanzania and Zanzibar are each treated as a "country."

${ }^{7}$ Fainboim and Lienert (2018) identify a fourth function: "Monitoring Macroeconomic and Fiscal Developments" (sub-functions 8, 9 and 10). In practice, the monitoring function is subsumed in the three main macro-fiscal functions identified in this paper.
} 
(and its components) and inflation. The MFD, or a forecasting working group, also forecast or make assumptions for exchange rates, interest rates, commodity prices and other variables needed for the budget process and government fiscal policy documents.

2. The medium-term fiscal framework. MFDs are either responsible for preparing all fiscal forecasts, particularly the medium-term fiscal forecasts, or bringing together components of the MTFF prepared by other units or departments.

3. Revenue forecasting. MFDs are often responsible for preparing forecasts of tax and non-tax revenues. MFDs are independent from the MoFs' revenue collection agency, which may also make detailed tax forecasts.

4. Expenditure forecasting. MFDs often produce the forecasts of total government expenditure over a three-year period, consistent with the MTFF, whereas the MoF's Budget Department coordinates the detailed expenditure estimates of each annual budget.

5. Debt projections and debt sustainability analysis. While MoF debt management offices are often tasked with this function, MFDs are also well-placed to forecast debt and to undertake debt sustainability analysis, given their familiarity with the underlying macroeconomic forecasts and the fiscal framework.

6. Fiscal policy analysis. With their medium-term perspective of the fiscal framework and their assessments of the economic cycle and debt sustainability, MFDs are well-placed to advise on the fiscal policy strategy, including the setting of fiscal rules in some countries.

7. Fiscal risk analysis. Increasingly, MFDs are tasked with analyzing fiscal risks. This includes assessing the risks from macroeconomic developments and forecast errors as well as coordinating information from other ministries and agencies on risks emanating from specific areas such as state-owned enterprises, public-private partnerships (PPPs), financial institutions, local governments, and the environment. The public sector balance sheet is one tool that MFDs in advanced countries are developing to assist with this analysis.

8. Monitoring macroeconomic developments. MFDs may produce in-year reports on domestic and international macroeconomic developments and their implications for the macroeconomic outlook and fiscal forecasts.

9. Monitoring the fiscal framework. MFDs are usually responsible for assessing whether fiscal outcomes are tracking consistently with fiscal forecasts, and identifying whether fiscal policy targets or fiscal rules would be breached.

10. Monitoring debt. Whereas managing the portfolio of debt is typically the responsibility of the MoF's debt management office, MFDs monitor debt developments to enable them to ascertain the causes of variations from the established fiscal and debt targets.

Given this wide range of functions, the MFD is often given responsibility for coordinating or preparing some or all the following documents:

- $\quad$ The medium-term fiscal (and debt) strategy document and projections.

- (with the Budget Department) The annual budget strategy document, and especially its alignment with the MTFF. 
- A fiscal risk statement.

- In-year reports of recent macro-fiscal developments.

- $\quad$ Reports on annual fiscal outcomes compared with the MTFF's first-year fiscal targets.

In many advanced countries, nearly all the above reports are prepared and published annually. Several reports may be updated at least once during the year, often at the time of the mid-term budget review. Other reports, including long-term fiscal sustainability analyses, reports on compliance with fiscal rules, pre- or post-election reports, are also prepared by MFDs in some countries.

\section{INSTITUTIONAL ARRANGEMENTS FOR THE MACRO-FISCAL FUNCTION OUTSIDE AFRICA}

Based on a review of MFDs in advanced and developing countries, Fainboim and Lienert (2018) observe three main organizational arrangements for the macro-fiscal function:

- A single MoF department or unit that performs all key macro-fiscal functions, which may include broader fiscal policy analysis.

- $\quad$ Various departments of the MoF that perform specific macro-fiscal functions collaboratively, with all such functions performed inside the MoF.

- $\quad$ Two or more ministries or government agencies that perform various macro-fiscal functions, with some oversight and coordination by the MoF.

Several countries, especially those with fiscal rules, have established an independent fiscal body that complements the work of MFDs. Such bodies may: analyze fiscal policies and the fiscal policy stance; prepare alternative fiscal projections to those prepared by the MoF; provide alternative costings for new fiscal policies; and prepare reports on the extent of compliance with the government's fiscal rules. Some independent bodies primarily support the parliament (Parliamentary Budget Offices-PBOs) while others perform a watchdog function independent of both the government and parliament, notably fiscal councils. ${ }^{8}$ It is rare for an independent fiscal body to prepare the official macro-fiscal forecasts used in the Government's annual budget. ${ }^{9}$

\section{ORgANIZATIONAL ARRANGEMENTS FOR THE MACRO-FISCAL FUNCTION IN 16 AfRICAN COUNTRIES}

This section examines the organizational arrangements for the key macro-fiscal functions in 16 African countries. It also reviews MFDs' size and budgets, as well as the salaries of MFD staff.

\footnotetext{
${ }^{8}$ For the functions, experiences and performance of fiscal councils in a wide range of countries, see Beetsma et al. (2018) and IMF (2013). In our sample, Uganda, Kenya, Malawi, Tanzania and Zimbabwe have established a PBO.

${ }^{9}$ The United Kingdom's Office of Budget Responsibility, Belgium's Planning Bureau and the Netherland's Bureau for Economic Policy Analysis are three rare cases; they produce the Governments' macro-fiscal forecasts. Belgium also has a fiscal council (established in 1936). See von Trapp et al. (2016).
} 


\section{Organizational Arrangements for the Macro-Fiscal Function}

After independence, many African countries prepared both a recurrent budget and a development budget. The latter was usually coordinated in a separate planning ministry responsible for centralizing multi-year public investment programs and for preparing National Development Plans covering five or more years. In recent years, many African countries have reformed their dual budgeting and national planning systems. Several countries now prepare public investment plans that, in principle, are an input for MTFFs and annual budgets (Allen et al., 2020). To support their planning reforms, several countries have also reformed planning ministries, sometimes by merging them into the MoF. In Ethiopia, for example, a "super-ministry" of finance, planning and economy was created in 1991, although this was de-merged in 2012.

Medium-term macroeconomic and fiscal forecasting, fiscal policy analysis and fiscal risk analysis were, in early 2018, performed by a single MoF department in eight of the 16 countries (Table 1). The MoFs of Madagascar, Zambia, and Zanzibar did not have a specific unit, division, or department of the MoF dedicated solely to macro-fiscal issues. In 2018, Zambia's macro-fiscal functions were shared between the MoF's Budget Department, the Cabinet Office of the President, and the MoF's Economic Management Department (the latter prepared the macroeconomic forecasts). In our survey, in only four of the 16 countries (Ethiopia, Madagascar, Malawi, and Zanzibar) planning ministries ("Commission" in Zanzibar) prepared the official macroeconomic projections. Subsequent to our survey, in 2019, Madagascar moved from column 3 to column 1 (see footnote to Annex 1).

Table 1. Organizational Arrangements for Macro-Fiscal Functions

(16 east and southern African countries)

\begin{tabular}{c|c|c}
\hline $\begin{array}{c}\text { One main MoF division or } \\
\text { department performs most } \\
\text { macro-fiscal functions }\end{array}$ & $\begin{array}{c}\text { Several MoF } \\
\text { Departments perform } \\
\text { macro-fiscal functions }\end{array}$ & $\begin{array}{c}\text { MoF department(s) plus a } \\
\text { planning/economy ministry } \\
\text { perform macro-fiscal functions }\end{array}$ \\
\hline $\begin{array}{c}\text { Eritrea*, Kenya, Lesotho*, } \\
\text { Mauritius, Rwanda, Tanzania, } \\
\text { Uganda, Zimbabwe }\end{array}$ & $\begin{array}{c}\text { Mozambique, Namibia, } \\
\text { Seychelles, Zambia }\end{array}$ & $\begin{array}{c}\text { Ethiopia, Madagascar, Malawi, } \\
\text { Zanzibar }\end{array}$ \\
& & \\
\hline
\end{tabular}

Source: Surveys of the 16 countries conducted in early 2018.

* = Fiscal risk analysis is not yet performed by the MFD.

In this table, macro-fiscal functions exclude debt sustainability analysis and debt monitoring.

We observe that, amongst our 16 countries with a reasonably comprehensive set of MFD outputs, most have adopted the "single division within the MoF" model for its MFD. Such an arrangement facilitates the coordination of macro-fiscal sub-functions. However, we would not conclude that there is single model for MFDs towards which all MoFs and planning/economy ministries should converge. The organizational arrangements actually adopted reflect the demands on the MFDs, their context (such as the size of the MFD, its resourcing, and its position in the budget process), and political decisions to retain or create a separate planning ministry with some macro-fiscal functions. 


\section{Distribution of macro-fiscal functions within MoF departments}

Figure 1 shows the distribution of the ten MFD sub-functions identified in Section II. Points to note are as follows:

- Macroeconomic projections, medium-term fiscal framework, and fiscal risk analysis (when prepared) are performed by the MFDs in most of the 16 countries.

- In nearly all countries, the MoF's Debt Department (or "debt management office") prepares the debt projections and monitors debt.

- Revenue projections are prepared in the MFDs in half of the 16 countries. In a few countries, there is Tax Policy Unit that prepares or collates revenue projections.

- Expenditure projections (aggregate and detailed) are prepared or collated by the Budget Department in half of the countries, and by the MFD in the other half.

Figure 1. Distribution of Macro-Fiscal Functions within MoFs

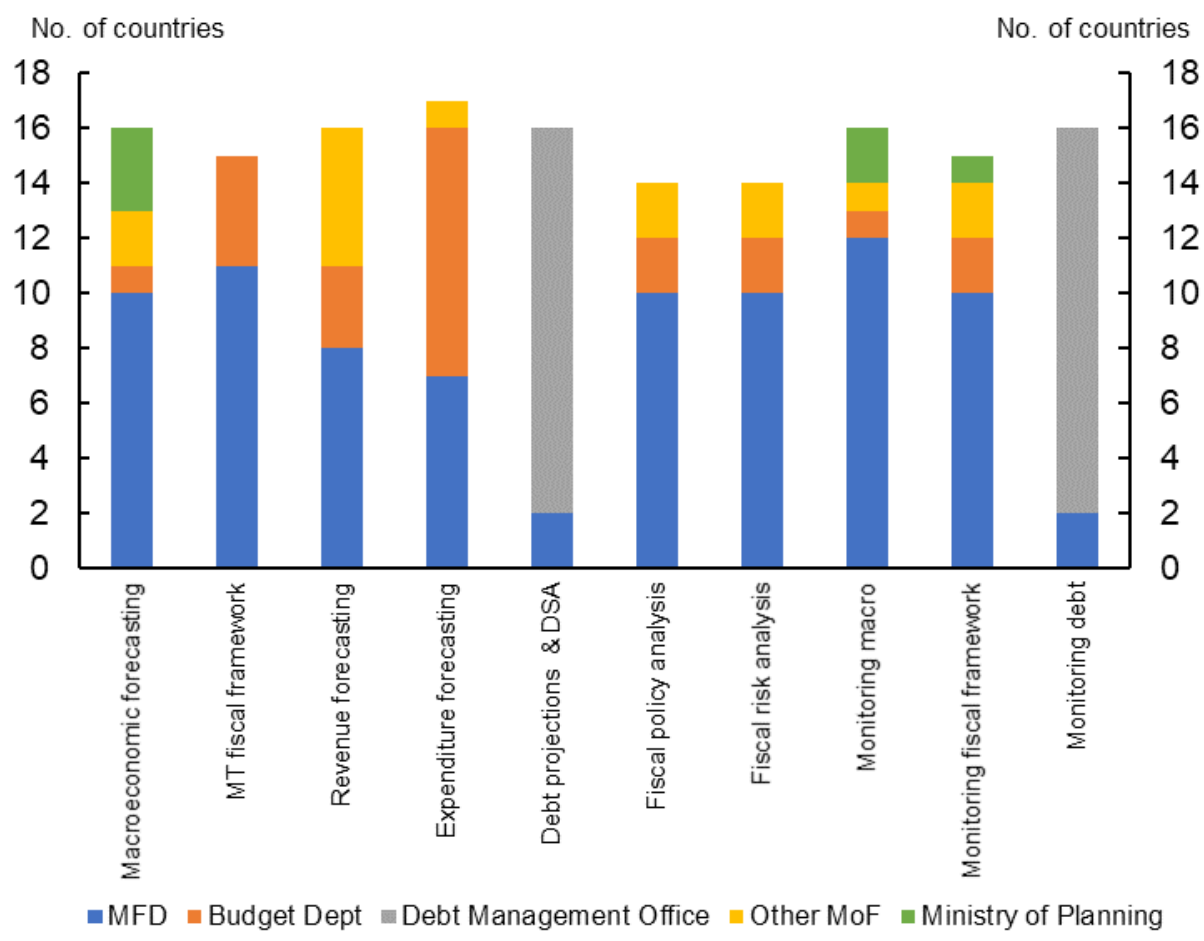

Source: Responses to the authors' survey of 16 countries.

Note: There are 17 observations for the 16 countries under expenditure forecasting. This is because Mozambique's survey attributed expenditure projection work to both the MFD and the Budget Department of the MoF. Independent forecasts by central banks, revenue authorities and parliamentary budget offices are not included in the survey results. "MT fiscal framework" refers to the medium term fiscal framework.

The performance of macroeconomic and revenue projections is presented in Section VI. While there is evidence that low turnover of the MFD's forecasting team improves the forecasts, we do 
not find convincing evidence from our limited sample that one set of organizational arrangements for forecasting performs better than another.

\section{Staff and budgets of macro-fiscal departments}

The number of staff working in MFDs varies enormously, reflecting particularly the variation in functional responsibilities (Figures 2 and 3). In 2018, nine of the 13 MFDs had less than 15 professional staff; in these countries, the number of staff ranged from three in Mauritius to 13 in Lesotho. Other MFDs are much larger, which reflects mainly the larger size of the country but also, to a lesser degree, the broader range of functions carried out. ${ }^{10}$ The MFDs in Mozambique, Kenya and Uganda had 22 to 30 professional staff. Tanzania's Policy Analysis Department had 61 professionals and is an outlier, also making up a much larger proportion of the overall ministry.

Figure 2. The Number of Staff and Macro-Fiscal sub-Functions of MFDs in 12 Countries

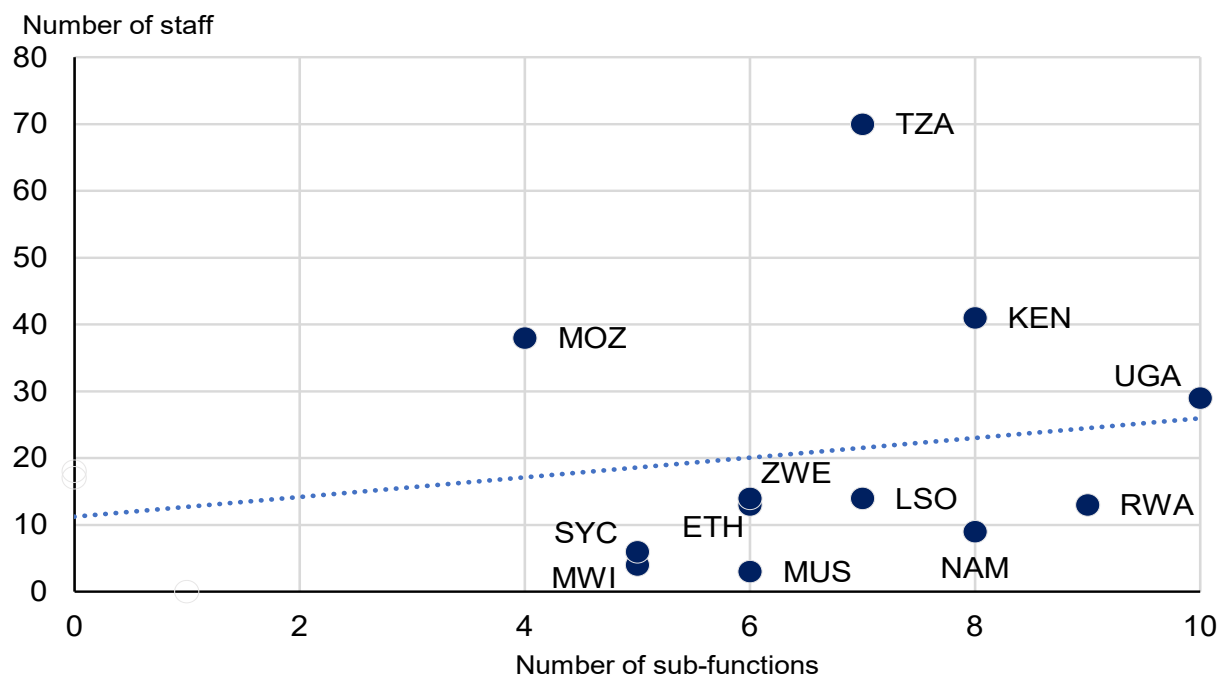

Source: Responses to the survey of 16 countries.

Note: The 10 sub-functions are those shown in Figure 1. The number of staff is based on actual staff employed in end-2017, not on staff positions. Country abbreviations are listed in Annex 1.

\footnotetext{
${ }^{10}$ Regressions of the number of staff against functions and a country's population showed significance of country population but not the number of functions.
} 
Figure 3. Proportion of Total MoF Staff in MFD

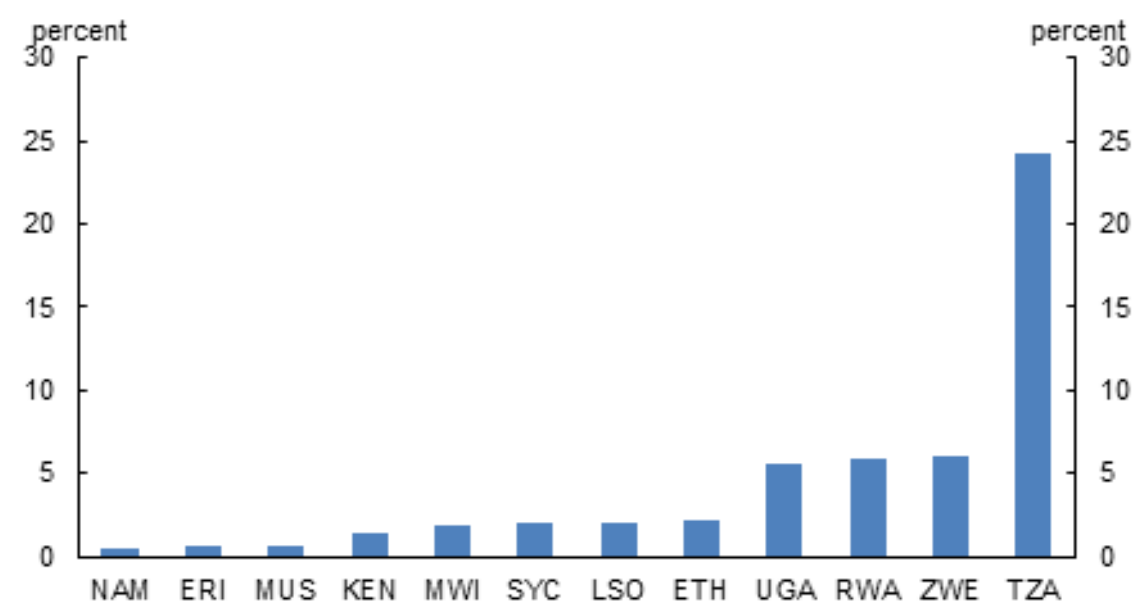

Source: Responses to the survey from 12 of the 16 countries.

Note: The number of staff is based on actual staff employed in end-2017, not on staff positions.

Mainly reflecting the number of staff, the budgets of the MFDs are quite small compared with the size of the MoFs' overall budgets. In five of the 10 countries for which data were available in early 2018 (Ethiopia, Kenya, Mauritius, Rwanda, and Uganda) the share of the MFD's annual budget was less than 1 percent of the MoF's budget; in the other countries the share was generally in the 1 to 3 percent range. Thus, when MoF managers "invest" in this important department of the MoF, by recruiting and/or training more staff, the cost of strengthening the MFD is quite low.

Staff turnover is quite high in some MFDs (Figure 4). As a result, the number of staff positions often exceeds the number of appointed staff because of vacancies. The annual turnover of the MFD staff is substantial (up to 45 percent) in Namibia and Seychelles; moderately high in Eritrea, Lesotho, Malawi, Zambia, Zanzibar and Zimbabwe; and lower in Ethiopia, Kenya, Mauritius, Rwanda and Uganda.

Figure 4. Rate of Staff Turnover in Selected MFDs

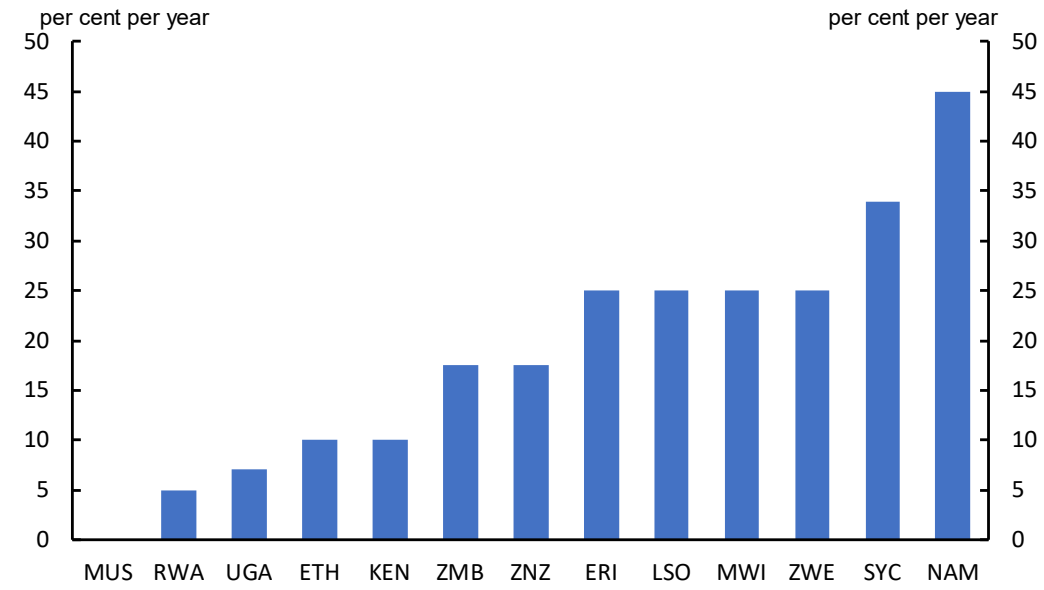

Source: Responses to the survey - 13 countries.

Note. We define turnover as the percent of staff in an MFD who are replaced each year. 
Turnover is often high because MFD staff, once fully trained, have skills and experience valuable in banks (including central banks), investment funds and international institutions. The salary differential between these other organizations and the MFD can be large; this is a major reason why skilled staff quit the MFD/MoF for employment elsewhere.

\section{The positioning of the Macro-Fiscal Department in Ministries of Finance}

In some countries, the MFD is a department within a directorate, whereas, in others, it is a division or unit of a department. Thus, the MFD director may or may not be on par with those of comparable departments.

The following three examples illustrate different configurations for the positioning of the MFD.

- $\quad$ Mauritius. Within the Ministry of Finance and Development, the Public Financial Management and Budgeting Directorate has several units, including a small Macro-Fiscal Unit (MFU) of three staff. The MFU is supported by Units for: Revenue (tax and nontax), Revenue Mobilisation (grants), Budget (expenditure), the Public Sector Investment Program (capital projects) and Debt Management. In total, 25 professional staff perform core MoF functions.

- Uganda. The Ministry of Finance, Planning and Economic Development was restructured in 2016. There are three main Directorates: Economic Affairs, Budget, and the Accountant General. The Macroeconomic Policy Department is a department within the Economic Affairs Directorate, which also includes a Tax Policy Department and three other departments.

- Kenya. The Directorate of Budget, Fiscal and Economic Affairs (one of five Directorates of the National Treasury), houses the MFD (the "Macro and Fiscal Affairs Department") which employs 29 professional staff. This department is divided into three divisions: Macro, Fiscal and Tax Units. Unlike Mauritius and Uganda, Kenya's MFD incorporates a tax unit (as opposed to a Tax Department on par with the MFD).

To some extent, the importance of the MFD within the MoF can be measured by comparing the salary of the heads of MoF departments with which the MFD collaborates closely. Figure 5 illustrates that the head of the MFD usually receives a salary similar to Debt Managers in many of our countries. In contrast, the Budget Director and especially the Accountant General are paid a higher salary in many of our countries. The Accountant General is often the head of an independent office with a different remuneration structure. This general pattern signals that MFDs are less-important departments of the MoF in several of our 16 countries. 


\section{Figure 5. Salary of MFD Department Heads Compared to Other MoF Senior Executives ${ }^{1}$}

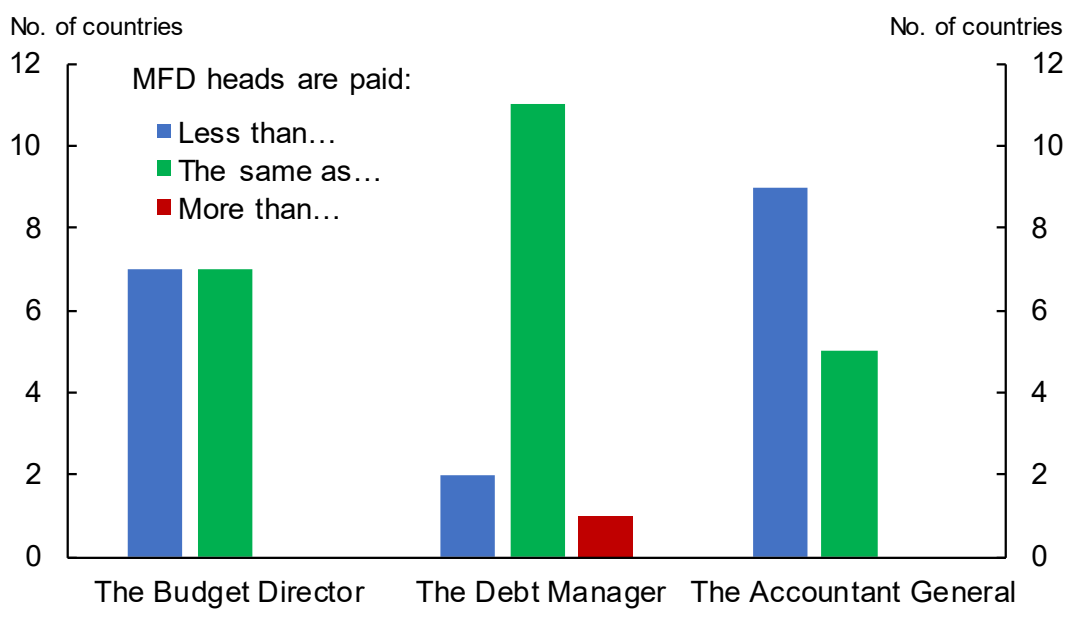

Source: Responses to the survey - 13 countries (2017).

1/ Madagascar, Zambia and Zanzibar did not report on the comparison of salary between the MFD head and the heads of other departments.

\section{Legal Framework}

Fiscal transparency laws may contain provisions that require key macro-fiscal outputs to be submitted to parliament, medium-term fiscal frameworks and/or numerical fiscal rules. Such laws impact favorably on the work of MFDs and their status within the MoF. Amended PFM laws or regulations are desirable for boosting the macro-fiscal orientation of the MoF. ${ }^{11}$ New laws can be complemented by secondary legislation that establishes the MFD and specifies its mandate, internal structure, etc. ${ }^{12}$

In our sample, the parliaments of 15 of the 16 countries have adopted a law that underpins their annual budget and PFM systems. Eritrea is the exception. However, only Kenya, Rwanda, Tanzania and Uganda have made substantive changes to their public finance laws in recent years; these provide a solid legal basis for the MoF's macro-fiscal functions. In the other 12 countries, there is scope for improving the adequacy of the legal provisions for the MFDs' outputs, notably those relating to fiscal transparency and publication of MTFFs.

The new laws in Kenya, Rwanda, Tanzania and Uganda appropriately require MTFF documents to be included in the budget documentation. Kenya's Public Finance Management Act 2012, for example, requires the Government to prepare: (a) a medium-term fiscal strategy: the Budget Policy Statement; and (b) a progress report on fiscal strategy implementation: the Budget Review

\footnotetext{
11 In francophone Africa, a new legal framework is considered a prerequisite for introducing fiscal reforms. For this reason, 14 countries of the CFA franc zones, along with the Democratic Republic of Congo have, in recent years, adopted a new public finance act and/or a fiscal transparency law, which require the preparation of a MTFF and the publication of various macro-fiscal documents (Table 1, Lienert, 2018).

12 Proposals to establish an MFD in many of our 16 countries have to be approved by the Public Service Commission (or equivalent), which can also sometimes block or delay the proposal.
} 
and Outlook Paper. The legal framework for PFM in Kenya and Uganda require the publication of reports on fiscal risks (annually), and pre- and post-election fiscal update reports.

Instead of adopting "permanent" quantitative fiscal rules (see Annex II) for ensuring macro-fiscal stability, these four countries' laws incorporate the "fiscal framework" approach similar to that adopted in Australia and New Zealand, which relies on:

"(i) legislated broad principles that guide the formulation of fiscal policy; (ii) detailed articulation of rolling budget plans and fiscal projections over short, medium, and long horizons; (iii) effective budget mechanisms and procedures designed to minimize deficit biases; and (iv) strong transparency requirements and public oversight" (p12, IMF, 2009).

There are, however, variants in the ways these countries' PFM laws constrain fiscal policy aggregates. For Kenya, Rwanda, and Tanzania, the law allows the Government to change the MTFF's fiscal policy aggregates every year (Table 2). In Uganda, a Charter of Fiscal Responsibility must be adopted soon after elections. Importantly, Uganda's Parliament is the final authority for approving the multi-year objectives for fiscal aggregates. In contrast, in the laws for the other three countries, the parliament reviews the MTFF and may make recommendations, but the laws do not explicitly require that Parliament approves the MTFF. ${ }^{13}$

Table 2. Legal Requirements for MTFFs in Four African Countries

\begin{tabular}{c|c|c|c|c}
\hline Year adopted & 2012 & Rwanda & Tanzania & Uganda \\
\hline $\begin{array}{c}\text { Title of MTFF } \\
\text { document }\end{array}$ & $\begin{array}{c}\text { Budget Policy } \\
\text { Statement }\end{array}$ & $\begin{array}{c}\text { Budget Framework } \\
\text { Paper }\end{array}$ & $\begin{array}{c}\text { Plan and Budget } \\
\text { Guidelines }\end{array}$ & $\begin{array}{c}\text { Charter of Fiscal } \\
\text { Responsibility }\end{array}$ \\
\hline $\begin{array}{c}\text { Projection } \\
\text { period }\end{array}$ & Medium-term & 3 years & Medium-term & $\begin{array}{c}\text { Not less than 3 } \\
\text { years }\end{array}$ \\
\hline $\begin{array}{c}\text { Frequency of } \\
\text { update }\end{array}$ & Annual & Annual & Not stated in the \\
law & $\begin{array}{c}\text { When Minister } \\
\text { initiates an } \\
\text { update }\end{array}$ \\
\hline $\begin{array}{c}\text { Final approving } \\
\text { authority }\end{array}$ & $\begin{array}{c}\text { Government } \\
\text { (Cabinet) }\end{array}$ & $\begin{array}{c}\text { Government } \\
\text { (Cabinet) }\end{array}$ & Government & Parliament \\
\hline
\end{tabular}

Sources: Selected articles of: Kenya Budget Act 2012; Rwanda: Organic Law on State Finances and Property, 2013; Tanzania Budget Act, 2015; Uganda PFM Act 2015. Tanzania Budget Law Training Manual; Uganda: Charter for Fiscal Responsibility 2016, and CSBAG, 2016.

\footnotetext{
${ }^{13}$ For example, in Kenya, the PFM Act 2012 allows Parliament to pass a resolution on the MTFF which the Cabinet Secretary shall take into account when finalizing the budget for the relevant financial year, i.e., the Government is not obliged to take on board amendments suggested by Parliament. Similarly, Rwanda's law (Art. 33) allows Parliament to submit comments on the Budget Framework Paper to the Cabinet, i.e., final approval is with the Cabinet of Ministers.
} 


\section{MACROECONOMIC AND FISCAL FORECASTING: TOOLS AND PERFORMANCE}

The majority of MFDs are tasked with the forecasts or assumptions for key macroeconomic parameters, such as real and nominal GDP, inflation, and the exchange rate. These macroeconomic forecasts provide inputs for the fiscal forecasts, especially those for revenues, thereby harmonizing the narrative between the budget and the economic outlook.

Macroeconomic parameters are also needed for debt sustainability analysis, which is sometimes undertaken by the MFD.

\section{Macroeconomic and fiscal forecasting tools}

The forecasting tools used by MFDs vary considerably in the region. Considerable use is made of the IMF's financial programming framework, which allows analysts to prepare macro-fiscal projections that are consistent across sectors of the economy. Twelve of the 16 countries use this framework for forecasting the four main macroeconomic accounts. ${ }^{14}$ The financial programming framework facilitates discussions with visiting IMF country teams who typically use the same framework.

Financial programming frameworks contain more information than is needed for MoFs to undertake their basic macro-fiscal functions. For instance, only central banks, not MoFs, need detailed monetary sector forecasts. Nonetheless, since MoFs need to analyze the macroeconomic impact of changes in fiscal policies, the financial programming framework, which is relatively easy to understand, has become prevalent in the region.

Forecasting tools should be compatible with the IT environment and the level of IT training of MFD officials, as acquisition and maintenance of new hardware and software for forecasting, and the reskilling of MFD staff, can be costly. All 16 countries use Excel spreadsheets for forecasting fiscal variables. Twelve countries rely exclusively on Excel for forecasting and three countries use a combination of EViews and Excel. Most countries (10 out of 16) still rely heavily on email and USB drives for maintaining and sharing files instead of more robust methods, like file-sharing servers.

The development and recurrent costs of building and maintaining macro-fiscal forecasting tools are usually significant-more so if different tools use different software platforms and require additional training. The Ugandan Ministry of Finance, Planning and Economic Development met the associated challenge by successfully building three economic models, using EViews and a proprietary computable general equilibrium package over a period of five years. This example illustrates that a MFD's investment in different software packages takes considerable resources and time to achieve and maintain user familiarity with the tools.

\section{Coverage of macro-fiscal forecasts}

The Fiscal Transparency Handbook (IMF, 2018) highlights that "accurate forecasts for key macroeconomic variables increase the chances that the revenue and expenditure projections will be reliable, particularly those of nominal GDP and inflation that feed directly into fiscal forecasts."

\footnotetext{
${ }^{14}$ The four economic accounts are: the real sector (GDP and its components); fiscal accounts; monetary sector; and external sector. IMF (1987) presents the theoretical basis for the financial programming framework.
} 
Macroeconomic forecasts or assumptions should cover, at a minimum, indicators of real and nominal GDP (and their components), inflation, the exchange rate and (where appropriate) key commodity export prices and volumes. Forecasts should extend over the medium term (three to five years) and be applied uniformly by all users.

Most countries in our survey forecast the key macroeconomic variables. The absence of certain forecasts (e.g., the components of GDP) reflects, to some extent, the unavailability or the poor quality of the underlying data. For instance, official national accounts are not produced in Malawi (where a business indicator survey is used as a proxy) or Eritrea (where the MFD uses proxies to estimate GDP). In most of the other countries, such data are of relatively modest quality and timeliness. Labor force surveys are not common in the region, so forecasts of the unemployment rate are not possible.

Table 3 indicates which countries prepare and publish one-year ahead and three-year ahead forecasts of three fundamental macro-fiscal variables. Although nearly all the surveyed countries prepare three-year ahead projections of real GDP, nominal GDP and revenues, in about half of the countries, these forecasts are produced internally, but not published regularly. Most countries devote resources to high-priority macro-fiscal forecasts, like revenue (for the budget) and real GDP growth (for the policy narrative). However, considerable efforts are still needed to strengthen the capacity of MFDs in the region to prepare and publish a wide range of mediumterm macro-fiscal variables.

Table 3. Production and Publication of Forecasts by Country

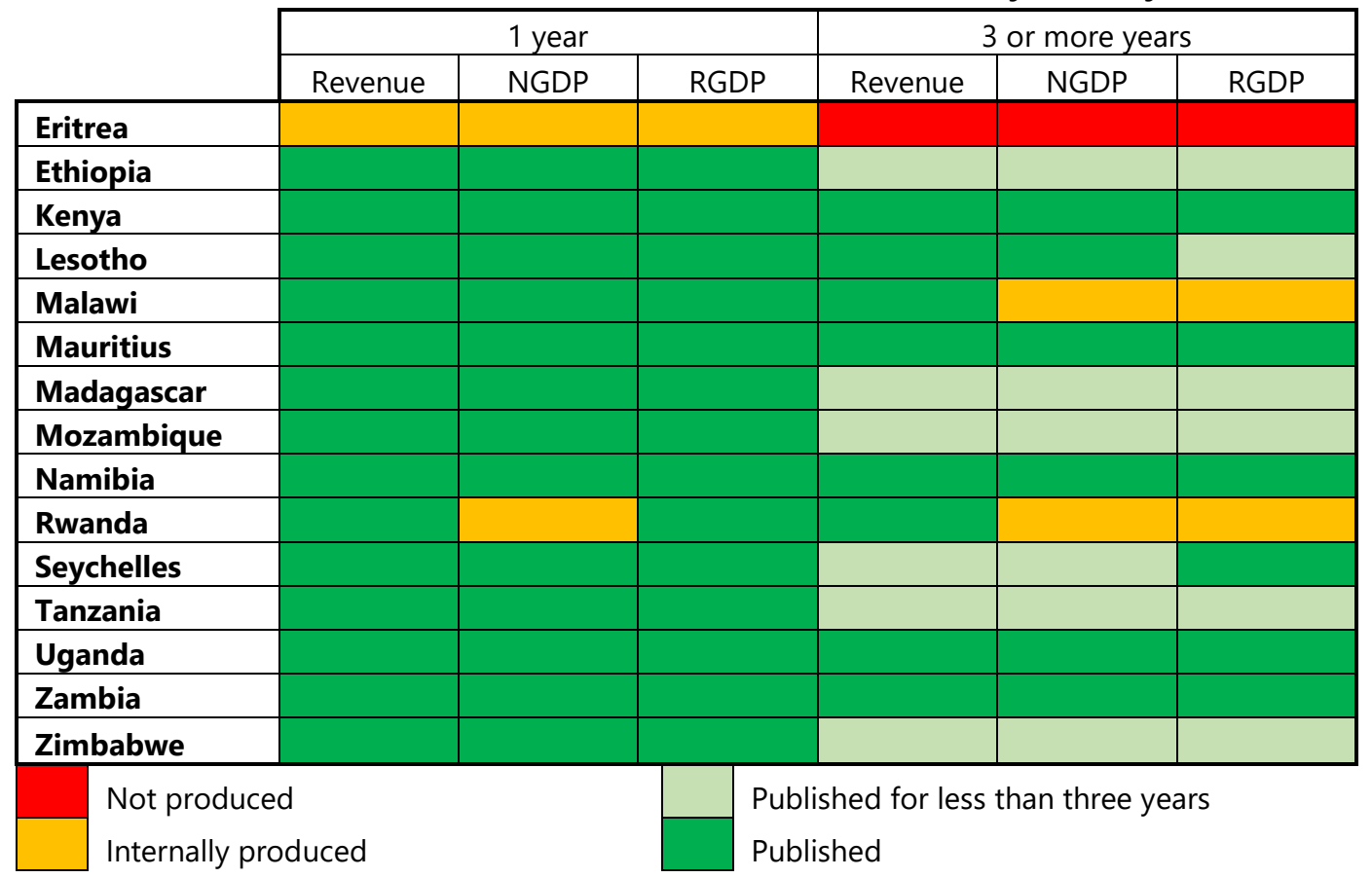

Source: Authors' database constructed from official budget or budget framework documents in each country in January 2018.

Note: NGDP is nominal GDP, RGDP is real GDP. 


\section{Quality of macro-fiscal forecasts}

Combined with efforts by National Statistics Offices to improve the timeliness and reliability of national accounts data, MFDs and forecasting working groups (in some countries ${ }^{15}$ ) are focusing on improving the quality and accuracy of the macro-fiscal forecasts. Also, of the 16 countries of our survey, five have conducted an IMF fiscal transparency evaluation, which reviewed their macro-fiscal forecasting performance (Kenya, Mozambique, Rwanda, Tanzania, and Uganda). ${ }^{16}$

Our analysis of the short- and medium-term forecasting performance of MFDs in the countries surveyed indicates the following results:

- Annual revenue forecasts. Performance has been mixed. The average forecast error (a measure of forecast bias) is positive in all but three countries, indicating that most countries are optimistic in their forecasting (Figure 6). Some countries (Tanzania, Lesotho, Kenya and Zimbabwe) have average forecast errors that exceed one percent of GDP. The average absolute error (a measure of accuracy) ranges from less than half a point of GDP (Mauritius) to over 3 percent of GDP (Lesotho) (Figure 7).

- Annual forecasts of nominal and real GDP. Projections have been similarly diverse in their performance (Figures 8 to 11). Nominal GDP forecast errors usually reflect a combination of real GDP forecast errors and GDP deflator (price) forecast errors. The bias in nominal GDP forecasts tends to be much lower than that in both the revenue and real GDP forecasts, implying a conservative bias in the price forecasts.

- Medium-term macro-fiscal forecasting performance (see Annex 3). Two- to three-yearahead forecasts of revenue-to-GDP tend to be optimistic (Figure A1), with higher absolute average errors (Figure A2) than the one-year forecast. The macroeconomic forecast errors are more mixed (Figures A3 to A6), perhaps reflecting that some countries use a simple reversion-to-trend rule when projecting macroeconomic aggregates for the outer years of the medium-term framework.

The underlying optimism bias in the forecasts is a useful target for improvement. In cases where there is a high mean absolute error, revenue forecasts might be improved with enhanced forecasting methods and tools (although the errors may reflect one-off economic shocks that are inherently hard to predict). Rwanda, Madagascar, Ethiopia, Mauritius, and Uganda stand out with both a low average absolute error and low average error. While each country has its unique context ${ }^{17}$ and challenges, there may be scope to understand better the organizational and technical frameworks used in those countries to achieve these results.

\footnotetext{
${ }^{15} \mathrm{~A}$ number of our 16 countries have macroeconomic framework working group arrangements, where officials from the MoF, the central bank, the statistical agency, the revenue authority and (in some cases) the petroleum or commodity-related ministry meet regularly to share data and discuss forecasts.

16 The evaluations for Kenya, Mozambique and Uganda are published (see https://www.imf.org/external/np/fad/trans/).

17 IMF program conditionality on fiscal targets could drive conservatism in revenue forecasts of some countries. For example, the database period underlying Figures 6 to 11 corresponds to a period of extensive IMF engagement in Madagascar.
} 
To improve forecasting performance, some countries assess the accuracy and quality of budget forecasts. For example, Kenya's MFD analyzes the quality of macro-fiscal forecasts and publishes a Statement of Fiscal Risks as an annex to its annual Budget Policy Statement (for details, see Annex 5). The analysis includes: a table of deviations of actual outcomes from forecasts; a discussion of the magnitudes of the divergences between the forecast and outcomes; and the main causes of those divergences. For assessing fiscal risks, Kenya also reports the sensitivity of key fiscal variables to changes in the underlying macroeconomic variables. Malawi's MoF has undertaken internal work to assess the quality of its macro-fiscal forecasts as part a step towards developing its first-ever fiscal risk statement. Analysts in the MoF have calculated the forecasts errors for nominal GDP growth and government revenue, and used these to present confidence intervals around their macro-fiscal forecasts.

Figure 6. Average Error of Non-Grants Revenue Forecasts

(2012/13-2018/19, percent of GDP)

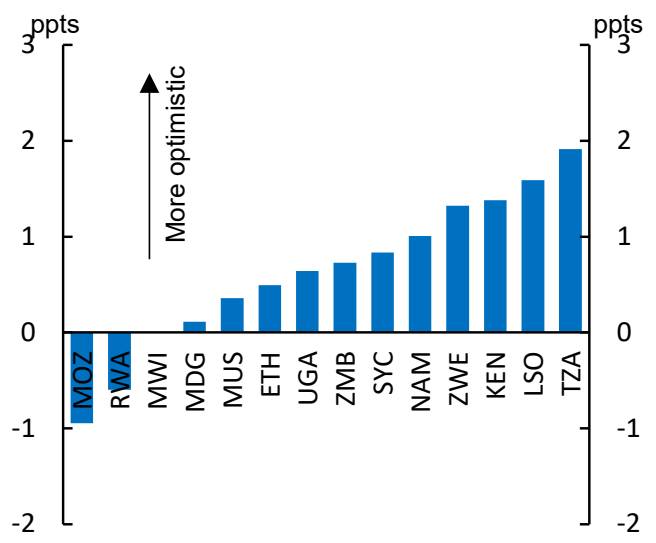

Figure 8. Average Error of Nominal GDP Growth Forecasts

(2012/13-2018/19, percent)

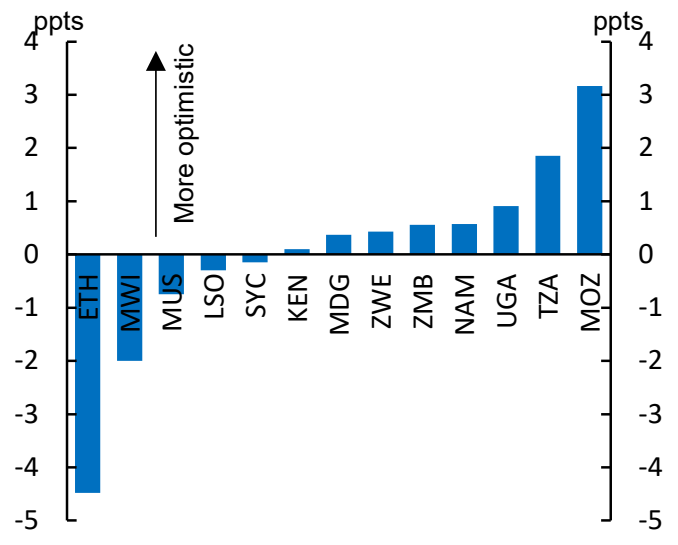

Figure 7. Average Absolute Error of NonGrants Revenue Forecasts

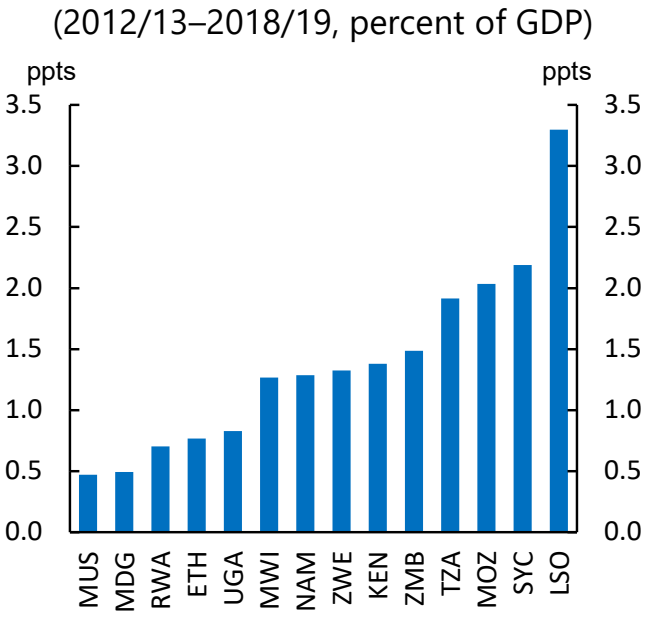

Figure 9: Average Absolute Error of Nominal GDP Growth Forecasts

(2012/13-2018/19, percent)

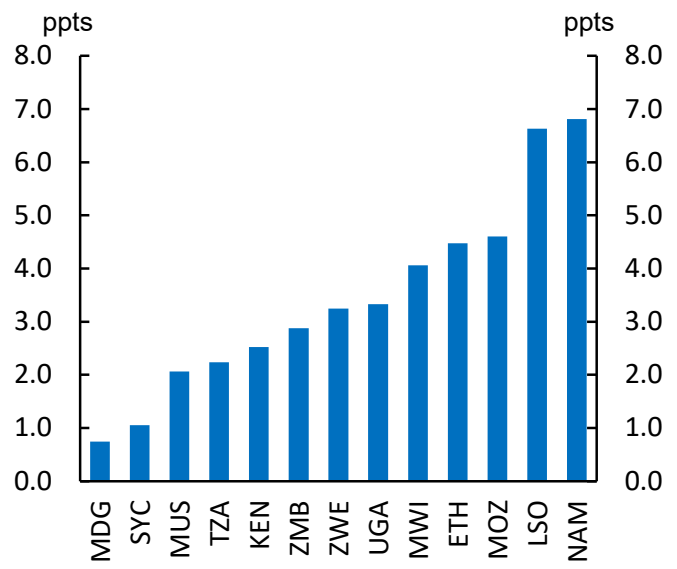


Figure 10. Average Error of Real GDP Growth Forecasts (2012/13-2017/18, percent)

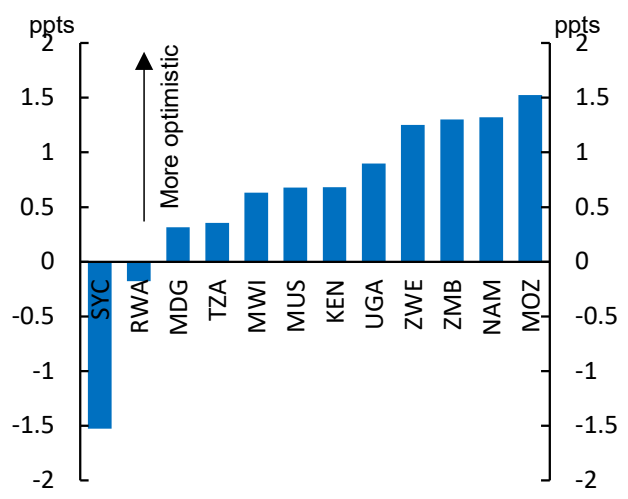

Figure 11. Average Absolute Error of Real GDP Growth Forecasts

(2012/13-2017/18, percent)

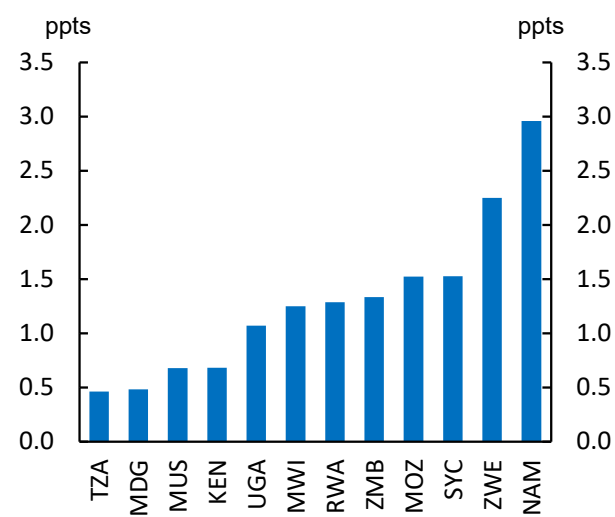

Source: Authors' database constructed from official budget or budget framework documents in each country. Note. See Annex 4 for exceptions and clarifications for these charts.

\section{OUTPUTS OF MACRO-FISCAL DEPARTMENTS}

Various macro-fiscal outputs are prepared during the annual budget cycle (Table 1, Fainboim and Lienert, 2018). The most important documents are those that lay out the medium-term fiscal strategy and projections, since a credible MTFF is the basis for a sound annual budget.

\section{Key budget documents prepared and published in the 16 countries}

To assess the depth of coverage of annual budget documents and the medium-term fiscal framework in our 16 countries, Box 1 shows 12 major macro-fiscal outputs of the MFDs. ${ }^{18}$ Some of these components overlap but are shown separately as some countries' budget documents focus nearly exclusively on fiscal developments in the upcoming 12 months.

Over half of the 16 countries prepare eight or more of the documents cited in Box 1 (Figure 12). However, despite progress in preparing documents that place the annual budget in a mediumterm perspective, ${ }^{19}$ nine countries were not regularly publishing a fiscal strategy document that describes their medium-term fiscal targets and policies.

\footnotetext{
${ }^{18}$ Box 1 does not include the long-term planning function, performed by a Planning Ministry or, in some cases, by a MoF. In several of our 16 countries, National Development and Socio-Economic Plans covering 5, 10 or even longer periods are prepared, as aspirational documents.

${ }^{19}$ See Figures 3.3 and 3.5 of World Bank, 2013.
} 


\section{Box 1. Key Macro-Fiscal Outputs}

\section{Annual fiscal strategy and projections}

1. Annual budget strategy describing at least the annual fiscal objectives, targets and policies.

2. Annual budget projections, at least for central government.

3. The impact of new revenue and expenditure policies.

4. Fiscal risks in the annual budget.

5. Mid-term review of the fiscal strategy.

6. End-year review of fiscal strategy implementation.

\section{Medium-term fiscal strategy and projections, including debt}

7. Medium-term budget strategy describing at least the medium-term fiscal objectives, targets and policies.

8. Medium-term fiscal projections, at least for central government.

9. Alternative medium-term fiscal projections, to illustrate the impact of different assumptions or policies.

10. The medium-term impact of new revenue and expenditure policies.

11. Fiscal risks over the medium-term.

12. Debt sustainability analysis, at least once a year.

Although the majority of the 16 countries prepare most of the key budget documents for internal use, there are significant variations amongst the countries when it comes to publishing these documents. In our study, none of the countries report that they publish all 12 documents pertaining to the annual budget and MTFF-the maximum is 11 documents (Mozambique see Figure 12). Two countries that produce relatively few of the 12 key budget documents (e.g., Madagascar, Namibia) publish all documents that are prepared internally. In contrast, some countries (including Eritrea, Ethiopia, Lesotho, Rwanda and Mauritius) do not publish several documents prepared by the MFD for internal MoF use.

\section{Figure 12. Budget Documents Prepared and Published in 16 Countries}

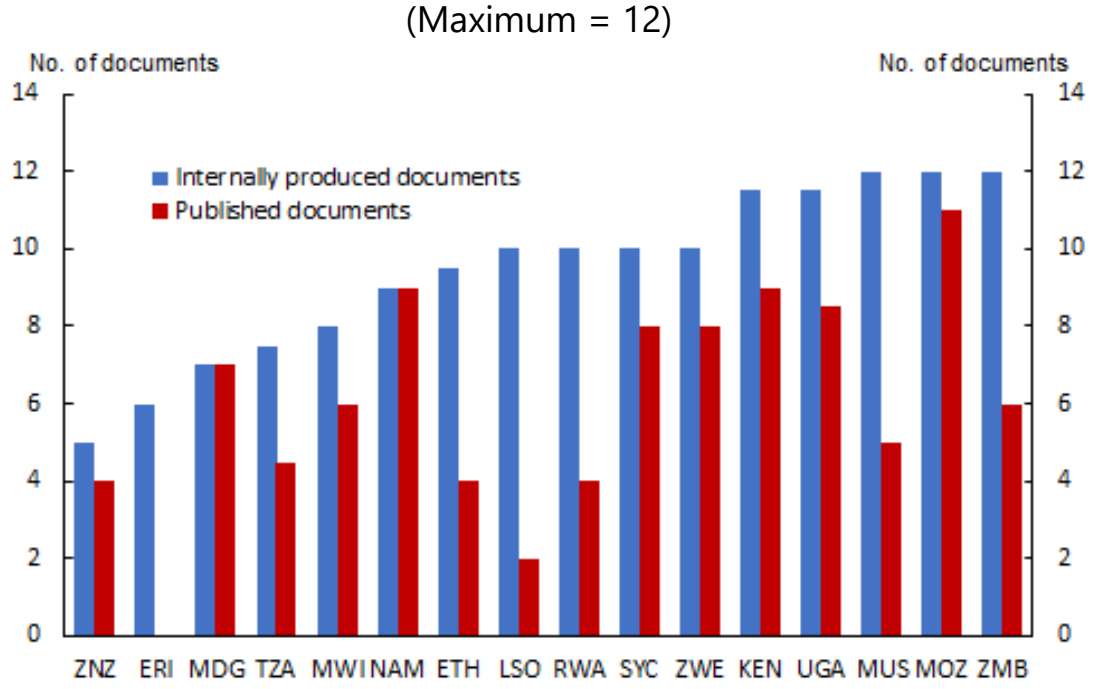

Source: Responses to authors' survey of 16 countries. 
Our findings on the non-publication of budget documents that are available internally are broadly consistent with other studies, notably the Open Budget Survey (OBS) which focuses on the publication of key annual budget documents. Until 2015, sub-Saharan African countries were becoming more transparent in publishing documents that had previously been available only internally (IBP, 2015; Lienert, 2018). However, between 2015 and 2019, the average overall score of the OBS declined in the nine countries (of our 16 countries) that were surveyed in 2015, 2017 and 2019. Slight improvements in some countries (sizeable in Zimbabwe in 2019) were more than offset by declines in Malawi, Tanzania (substantial) and Zambia (IBP, 2020).

In many cases, these adverse developments arise because previously published documents were no longer available in the public domain. Hiller et al. (2018) suggest that the lack of institutionalization of budget transparency practices is a major explanatory factor for the reversal. Allen et al. (2017) also note that early successes were not sustained; these authors recommended that "countries should focus on building their capability in macro-fiscal forecasting and analysis, and in improving the credibility of the annual budget process."

MFDs may also be responsible for producing other in-year, medium-term, and long-term analyses and reports, often as complements to the 12 key documents listed in Box 1. Table 4 helps to identify where publication of material is widespread, and where challenges remain. For instance, all countries except Eritrea prepare medium-term fiscal projections, suggesting that the emphasis should be on improving their quality. Longer-term fiscal projections (for at least five years) are prepared periodically by a much smaller set of countries, and these are usually linked to 5-year (or long-term) socio-economic development plans.

Table 4. Production and Publication of an Extended Set of Macro-Fiscal Documents

\begin{tabular}{|c|c|c|c|c|c|c|c|c|c|c|c|c|c|c|c|c|}
\hline & \multicolumn{3}{|c|}{ In-year } & \multicolumn{5}{|c|}{ Annual } & \multicolumn{5}{|c|}{ Medium-term } & \multicolumn{3}{|c|}{ Long-term } \\
\hline & 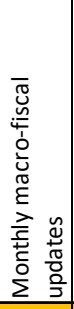 & 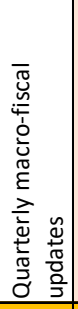 & 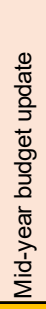 & 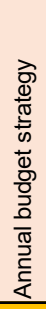 & 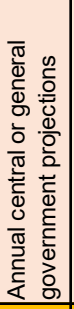 & 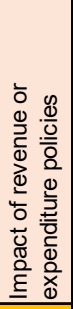 & 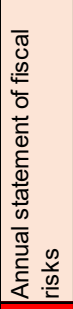 & $\begin{array}{l}\frac{0}{\pi} \\
\frac{\pi}{2} \\
\frac{0}{3} \\
\frac{1}{\pi} \\
0 \\
\frac{1}{1} \\
\frac{1}{0} \\
\frac{1}{2} \\
\text { W } \\
\end{array}$ & 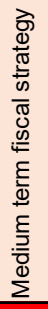 & 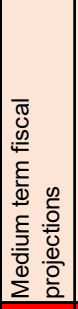 & 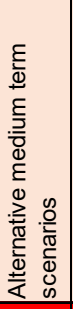 & 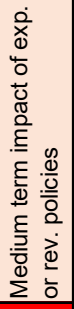 & 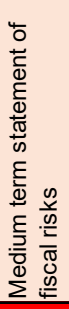 & 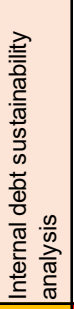 & 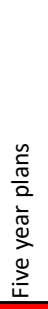 & 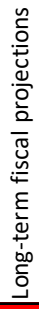 \\
\hline \multicolumn{17}{|l|}{ Eritrea } \\
\hline \multicolumn{17}{|l|}{ Ethiopia } \\
\hline \multicolumn{17}{|l|}{ Kenya } \\
\hline \multicolumn{17}{|l|}{ Lesotho } \\
\hline \multicolumn{17}{|l|}{ Malawi } \\
\hline \multicolumn{17}{|l|}{ Mauritius } \\
\hline \multicolumn{17}{|c|}{ Madagascar } \\
\hline \multicolumn{17}{|c|}{ Mozambique } \\
\hline \multicolumn{17}{|c|}{ Namibia } \\
\hline \multicolumn{17}{|l|}{ Rwanda } \\
\hline \multicolumn{17}{|l|}{ Seychelles } \\
\hline \multicolumn{17}{|l|}{ Tanzania } \\
\hline \multicolumn{17}{|l|}{ Uganda } \\
\hline \multicolumn{17}{|l|}{ Zambia } \\
\hline \multicolumn{17}{|l|}{ Zanzibar } \\
\hline Zimbabwe & & & & & & & & & & & & & & & & \\
\hline
\end{tabular}

Source: Authorities survey responses, January 2018.

Note: Green indicates the document is published; orange indicates the document is produced for internal use; red indicates no document is produced. The table does not consider publications by central banks. 
Fiscal risk analysis is a relatively new activity for MFDs in Africa. The IMF Fiscal Transparency Code recommends that governments should disclose, analyze, and manage fiscal risks. However, in early 2018, six of our 16 countries had not begun to produce even a rudimentary fiscal risk statement.

\section{Challenges and Policy Orientations for Strengthening the Macro-Fiscal FUNCTION}

This section first examines the results from the forecast performance analysis and MFD characteristics. Subsequently it reviews the major challenges for performing macro-fiscal activities in the MoFs of the 16 countries, before discussing measures for strengthening the macro-fiscal function in the region.

\section{Forecast performance and MFD characteristics}

A panel regression of the average forecast errors and average absolute forecast errors for revenue (Figures 6 and 7) against relevant survey results is presented in Table 5. Notwithstanding the small size of the panel dataset and the weakness of any statistical analyses of the data, some tentative conclusions can be drawn.

The regressions suggest that an increase in publication is weakly associated with a lower average forecast error and has a slightly stronger association with the absolute forecast error. Larger forecasting teams (proxied by MFD staff numbers) tend to be associated with poorer forecasting performance. This may reflect highly-skilled forecasters in a few countries' small teams, as opposed to less-focused forecasting efforts in MFDs with a wider mandate. High staff turnover is, unsurprisingly, a stronger predictor of more biased and less accurate forecasts. A variable to represent the complexity of the framework (whether software other than Excel is used) is insignificant in the average error forecast and is weakly (but positively) associated with the absolute error.

Table 5. Regressions of Forecast Performance Against MFD Characteristics

\begin{tabular}{l|c|c}
\hline & Average Error (ppt) & Average Absolute Error (ppt) \\
\hline Constant & 0.619 & 1.472 \\
& $(0.680)$ & $(0.610)$ \\
\hline \multirow{2}{*}{ Number of staff (Figure 2) } & 0.022 & 0.018 \\
& $(0.012)^{\star}$ & $(0.009)^{\star}$ \\
\hline Turnover rate (Figure 4) & 0.033 & 0.048 \\
& $(0.019)$ & $(0.016)^{\star \star}$ \\
\hline Number of publications & -0.156 & -0.223 \\
(Figure 12) & $(0.101)$ & $(0.102)^{\star}$ \\
\hline Software other than Excel & & 0.878 \\
(Section VI) & & $(0.494)$ \\
\hline $\mathbf{R}^{\mathbf{2}}$ & 0.36 & 0.57 \\
\hline
\end{tabular}

Note: 14 observations. Figures in brackets are standard errors. ${ }^{* *}$ indicates significance at the 5 percent level, *indicates significance at the 10 percent level. 


\section{Challenges facing MoFs' macro-fiscal roles in the 16 countries}

Figure 13 summarizes the perceived difficulties and ranks them according to how commonly the challenges were reported across the 16 countries.

Figure 13. Challenges in Performing Macro-Fiscal Functions in East and Southern African MFDs

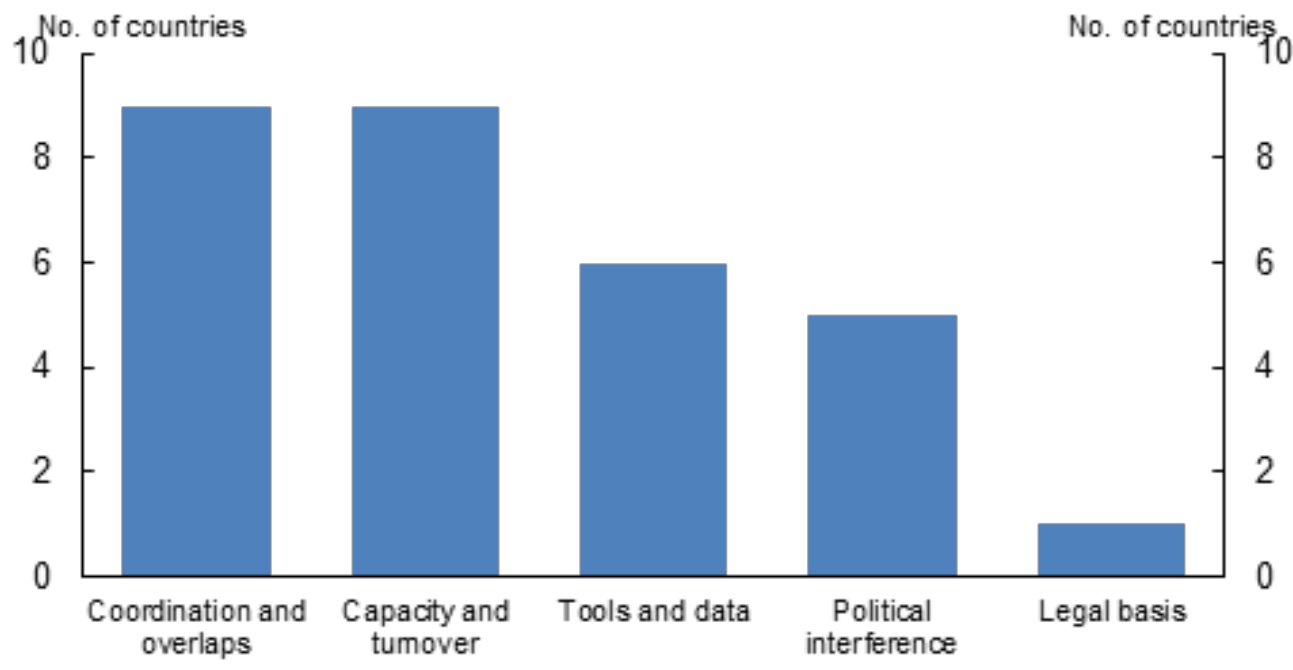

Source: Surveys of the 16 countries.

\section{Inadequate coordination and overlaps}

Poor internal coordination within the MoF (or outside MoF, when the MFD is elsewhere) appears to be a widespread problem. As a result, the MFD does not obtain easily, or regularly, all the necessary data and information from other MoF departments. This may be due to bureaucratic silos, poor internal communications, or unclear mandates of the MFD and other MoF departments, including responsibilities for timely data-sharing. Weak internal coordination can result in a 'drifting anchor' of macroeconomic targets and forecasts in the medium-term fiscal framework or pose a potentially serious fiscal risk from difficult-to-detect macroeconomic inconsistencies in the budget forecasts and estimates. ${ }^{20}$

\section{Insufficient capacity and high turnover}

The challenge to find, train, then retain staff with strong quantitative skills to forecast and analyze macroeconomic and fiscal variables is acute in our 16 countries (Figure 4). Given salary differentials within the MoF (Figure 5) and outside the MoF, once MFD staff have received adequate training to perform their MFD functions, there are strong incentives to quit.

\footnotetext{
${ }^{20}$ For example, expenditure forecasts may be based on a low inflation outlook while the revenue forecasts are based on a high inflation outlook, resulting in over-optimistic budget balance projections. This inconsistency is difficult to detect.
} 


\section{Tools and data: ease of use, comprehensiveness, and timeliness of MFD outputs}

The MFDs of the 16 countries cited the complexity of forecasting and analytical tools as a constraint to their sustainability and use. In several cases, forecasting tools developed by external consultants proved to be difficult to maintain and prone to error. There is no evidence that increased sophistication improves the accuracy of the forecasts (Table 5). The main lesson is to avoid generic tools not tailored to fit with the specific needs of the MFD.

\section{Lack of commitment and political interference}

Even in countries where medium-term projections are published, there is often not a strong political attachment (outside the MoF) to achieving the agreed medium-term fiscal objectives. Not infrequently, the annual budget's objectives have been derailed following a political decision to increase government spending in a specific area or to parachute in a new infrastructure project without any budget financing. Political interference is one reason for optimism bias in forecasts of revenue and, to a lesser extent, GDP. Interference can take different forms, from gentle encouragement to change forecasts to the direct replacement of forecasts.

\section{Addressing macro-fiscal challenges: some policy proposals}

This subsection examines ten areas where the government could take measures to improve the operation of the macro-fiscal function.

- Recognizing the importance of macro-fiscal analysis. The MFD should have a clear mandate, to allow it to have an active voice in all macro-fiscal strategy and policy planning discussions. To recognize the MFD as a MoF key department, it should be placed on par with other MoF departments, including the Budget, Debt Management, and Accountant General's Departments. A functional review of the MoF and (for some countries) a parallel review of planning ministries/agencies can be useful (Allen et. al. 2015).

- Ensuring ongoing staff training. On-the-job training by peers within the MFD is an effective way of learning how to analyze fiscal policies and for preparing medium-term macro-fiscal strategies and projections. Training programs may need to be strengthened, with a focus on: using spreadsheets; producing analytical reports; writing influentially for policymakers; and clearly presenting macro-fiscal analysis and forecasts. On-line training and other specialized training can complement in-house training, to deepen knowledge of specific macro-fiscal subjects and to learn from how other countries perform macrofiscal tasks. MFD staff could undertake IMF online training courses, ${ }^{21}$ attend off-site training courses and regional workshops offered by AFRITACs.

- Examining incentives for motivating staff. Higher salaries for MFDs and MoF staff are usually not feasible as the pay differentials with non-civil service jobs are too large to be bridged. Faced with the reality of the budgetary cost of higher salaries and low tax/GDP

\footnotetext{
${ }^{21}$ See https://www.edx.org/school/imfx for IMF courses relevant to macro-fiscal analysts.
} 
ratios, MoF managers could focus on non-salary motivations for MFD staff. In addition to upgrading the MFD's status and training, these could include: (1) developing tools and processes that ease the task of preparing forecasts (especially important when MFD staff size is small, turnover is high, and analytical and forecasting skills are scarce); and (2) providing MFD staff with opportunities to present their technical work to MoF directors and the Minister of Finance.

- Enhancing data quality and coverage. Specific weaknesses in the comprehensiveness and timeliness of macroeconomic and fiscal data need to be identified, then rectified. Data improvement plans should prioritize the most urgent actions. For some countries, this would be to improve the quality and timeliness of the national accounts, price indices, and central government fiscal data. For other countries, the emphasis could be on improving the coverage of government fiscal data and projections, to include the revenue, spending and financing of subnational governments, autonomous government agencies and extrabudgetary funds. For more advanced countries in the region, the emphasis may also be on collecting supplementary data required for fiscal risk analyses, e.g., reviewing PPP contracts to assess PPP risks.

- Improving internal and external coordination. The MFD needs to be proactive in consulting with other MoF departments, especially the Budget, Revenue, and Debt Departments, and the Accountant-General's Office. The MFD should participate in, or initiate the formation of, an inter-ministry working group that shares data, assumptions and other information for preparing the macroeconomic and fiscal projections. A collaborative approach for developing macroeconomic projections is best when human resources are limited. Formal memoranda of understanding for the exchange of data, etc., could be drawn up between relevant parties such as the central bank, the national statistics office, the revenue authority, and the ministry of economy and/or planning.

- Developing forecasting tools compatible with the IT environment and the skill sets of officials. When resources are constrained and forecasts must be prepared within a tight budget calendar, it is unwise to develop large-scale models that are incomprehensible to many users and depend on one or two experts. Simplicity must be prioritized when MFD staff turnover is high (see Table 1, Battersby and Lautier, 2019). Since revenue projections are often driven by economic parameters, whereas expenditures are programmed by the Government to attain fiscal objectives, the MFD (or the MoF's Tax Policy Department, should it exist) ${ }^{22}$ should prioritize developing modules for projecting the main revenue categories, aggregate expenditures consistent with medium-term targets of the MTFF.

- Improving the quality of macroeconomic and fiscal forecasts. Forecast performance reviews should be conducted and published, to improve forecasting models and methods, to enhance budget transparency, and to build public confidence in the macrofiscal forecasts and the MTFF. Relevant guidance is provided in the discussion of Principle 2.4.3 of IMF (2018). The establishment of an independent fiscal institution (see

\footnotetext{
22 Grote (2017) discusses the roles of Tax Policy Units within a MoF and how to establish such units.
} 
Footnote 9) could possibly be helpful for improving the quality of macroeconomic and fiscal forecasts. ${ }^{23}$

- Developing fiscal risk analysis. For some countries, rudimentary fiscal risk analysis should begin. Countries should initially focus on the sensitivity analysis of macroeconomic and fiscal forecasts, and learn from the experience of countries in the region. ${ }^{24}$ As capacity and information systems improve, the analysis should evolve, to identify specific risks, deepen the analysis of those risks, and develop risk mitigation strategies.

- Improving political commitment to the MTFF and annual budget targets. Staff of MoFs may feel powerless in the face of political interference that counteracts sound budgetary policies. The MFD and MoF senior staff have some influence through their advisory role, including the formulation of proposals to reverse political fiscal policy decisions based on expediency. For example, the MFD can estimate the budgetary impact of populist policy choices on the MTFF previously endorsed at political level and share its findings with the Minister of Finance and (if possible) the public. MFD/MoF staff can also illustrate how a top-down budgeting procedure has been helpful in other countries' quests for achieving fiscal stability. ${ }^{25}$

- Revising the legal framework. Most of the countries in the region could benefit from revamping their legal framework, by adding provisions to require MFD outputs, notably a medium-term budget strategy and MTFF, to publish forward-looking budget documents and fiscal risk statements, and to introduce other transparency and accountability requirements. The MFD could spearhead amendments to PFM laws.

\section{SUMmaRY AND CONCLUSIONS}

MFDs can play a crucial role in assisting political authorities to attain macro-fiscal stability. This paper reviews the functions, organizational arrangements and outputs of the MFDs in 16 east and southern African countries. It finds considerable diversity in the functions performed, the structure, size, status (within the MoF) and legal frameworks for the MFDs of the region. Macroeconomic and fiscal forecast performance is variable but tends to be better in smaller MFDs with lower staff turnover and greater transparency in publishing their macro-fiscal outputs.

We see merit in establishing the MFD as a single department of the MoF with a wide mandate, covering most of the macro-fiscal functions discussed in this paper. Such an arrangement would facilitate internal coordination, which is identified as a major challenge in most MoFs of the region. Many MFDs need to be recognized as a key department of the MoF, with broadly comparable status to the Budget, Treasury, Debt Management and Accountant General

\footnotetext{
${ }^{23}$ Independent fiscal councils have been established in Kenya, Malawi, Tanzania, and Uganda.

24 Kenya's fiscal risk statement is relatively comprehensive (Annex 5). Countries in the region that do not yet prepare a fiscal risk statement could learn from Kenya, South Africa (not included in this study) and Uganda. See also Battersby and Rosenberg (2019).

${ }^{25}$ For more on top-down budgeting, see Dorotinsky and Watkins (2013) and Robinson (2012).
} 
Departments. Coordination with other central government agencies such as those charged with national planning and statistics, as well as the central bank, could also be improved, especially for macro-fiscal forecasting issues.

Most MFDs face major challenges to recruit and retain skilled staff. Given limited budgetary resources for salary increases, training programs and other nonfinancial incentives are needed on an ongoing basis. The number of MFD staff and the MFD's internal salary structure (relative to other MoF departments) should be adapted to the breadth of the MFD's functions and its mandated outputs.

To manage political interference and to draw attention to the importance of the work of MFDs, Finance Ministries should commit to periodic postmortems of the macroeconomic and fiscal forecasts. Such reviews could be done in-house or, alternatively, comprehensive evaluations could be carried out by external consultants. Exposure of macro-fiscal forecasts to an external review would mitigate the pressure to bias the forecasts and help build the credibility and reputation of the MFD.

Fiscal risk analysis has begun in a few countries of the region. As capacity develops, such analysis needs to become deeper and more widespread. Finally, to enhance the comprehensiveness of macro-fiscal outputs, the PFM laws of some countries could be amended, to include provisions on medium-term fiscal frameworks, fiscal risks and other core MFD outputs. 


\section{BIBLIOGRAPHY}

Allen, Richard, Yasemin Hurcan, Peter Murphy, Maximilien Queyranne, and Sami Ylaoutinen, 2015, "The Evolving Functions and Organization of Finance Ministries," IMF Working Paper No. 15/232, www.imf.org.

Allen, Richard, Taz Chaponda, Lesley Fisher and Rohini Ray, 2017, "Medium-Term Budget Frameworks in Sub-Saharan African Countries," IMF Working Paper No. 17/203, www.imf.org.

Allen, Richard, Mary Betley, Carolina Renteria and Ashni Singh, 2020, "Integrating Infrastructure Planning and Budgeting," Chapter 12 in Schwartz Gerd, Manal Fouad, Torben Hansen, and Genevieve Verdier (eds.), Well Spent: How Strong Infrastructure Governance Can End Waste in Public Investment (Washington DC: International Monetary Fund).

Battersby, Bryn and Eric Lautier, 2019, Developing Macro-Fiscal Forecasting Frameworks in East Africa, https://blog-pfm.imf.org, August 22.

Battersby, Bryn and Greg Rosenberg, 2019, Capacity-building for Fiscal Risks in East Africa, https://blog-pfm.imf.org, September 3.

Beestma, Roel M. W. J., Xavier Debrun, Xiangming Fang, Young Kim, Victor Duarte Lledo, Samba Mbaye and Xiaoxiao Zhang, 2018, "Independent Fiscal Councils: Recent Trends and Performance", IMF Working Paper No. 18/68," www.imf.org.

CABRI, 2015a, "Budget Practices and Procedures in Africa 2015: Understanding Fiscal Management Practices", Collaborative Africa Budget Reform Initiative (CABRI), www.cabrisbo.org/en/publications/budget-practices-and-procedures-in-africa-2015-1.

CABRI, 2015b, "Budget Practices and Procedures in Africa 2015: Probing Finance Ministries Power and Size", Collaborative Africa Budget Reform Initiative (CABRI), www.cabrisbo.org/en/publications/budget-practices-and-procedures-in-africa-2015-2

CSBAG, 2016, "Understanding [Uganda's] Public Finance Management Act, 2015", Civil Society Budget Advocacy Group (CSBAG), Ntinda, Uganda, http://csbag.org/wpcontent/uploads/2016/10/Understanding-the-Public-Finance-Management-Act-2015.pdf.

Dorotinsky W. and J. Watkins, 2013, "Common Practices in Setting Expenditure Ceilings within National Budgets," World Bank GET Note, http://siteresources.worldbank.org.

Fainboim, Israel and lan Lienert, 2018, "The Macrofiscal Function and its Organizational Arrangements," IMF Technical Notes and Manuals, TNM/18/04, www.imf.org.

Grote, Martin, 2017, "How to Establish a Tax Policy Unit," How To Note 17/02, International Monetary Fund, www.imf.org.

Hiller, Daniel, Jason Lakin and Joel Friedman, 2018, "Sub-Saharan Africa: Failure to Institutionalize Past Gains Weakens Transparency," IBP Blog, March, www.internationalbudget.org. 
International Budget Partnership, 2015, Open Budget Survey 2015, International Budget Partnership (IBP), www.internationalbudget.org/wp-content/uploads/OBS2015-ReportEnglish.pdf.

2020, Open Budget Survey 2019, International Budget Partnership (IBP), https://survey.internationalbudget.org/\#timeline.

International Monetary Fund, 1987, "Theoretical Aspects of the Design of Fund-Supported Adjustment Programs," Occasional Paper No. 55 (Washington: International Monetary Fund). 2009, "Fiscal Rules-Anchoring Expectations for Sustainable Public Finances," www.imf.org.

2013, "The Functions and Impact of Fiscal Councils," IMF Policy Paper, July 16, www.imf.org/external/np/pp/eng/2013/071613.pdf

2017, Mauritius: Staff Report for the Article IV Consultation", www.imf.org.

2018, "Fiscal Transparency Handbook", www.imf.org.

Last Duncan, Chadi Abdallah, Jason Harris, Florence Kuteesa, Guy Anderson, Fazeer Sheik Rahim, and Lesley Fisher, 2016, "Kenya Fiscal Transparency Evaluation," IMF Country Report 16/221, www.imf.org/external/pubs/ft/scr/2016/cr16221.pdf.

Lawson, Andrew and Finn Hedvall, Cecilie Thue-Hansen, Gonzalo Contreras, 2017, "Tanzania Mainland - Public Expenditure \& Financial Accountability (PEFA) Performance Assessment Report," https://pefa.org/assessments/tanzania-2017.

Lienert, lan, 2013, "Performance and Programme-Based Budgeting in Africa: Status Report," Collaborative African Budget Reform Initiative (CABRI), November 2013. www.cabrisbo.org/en/publications-and-documents.

Lienert, Ian, 2018, "Is the Open Budget Survey Biased Against Francophone Countries", IBP ,Washington DC, www.internationalbudget.org.

Lledó, Victor, Sungwook Yoon, Xiangming Fang, Samba Mbaye, and Young Kim, 2017, "Fiscal Rules at a Glance," IMF Background Paper, www.imf.org.

Robinson, Marc, 2012, "Aggregate Expenditure Ceilings and Allocative Flexibility," OECD Journal on Budgeting, Vol. 2012/3, http://dx.doi.org/10.1787/budget-12-5k468nqj1f7g

Schick, Allen, 2001, "The Changing Role of the Central Budget Office", OECD Journal on Budgeting, Vol. 1/1. http://dx.doi.org/10.1787/budget-v1-art3-en.

von Trapp, Lisa, lan Lienert, and Joachim Wehner, 2016, "Principles for Independent Fiscal Institutions and Case Studies, OECD Journal of Budgeting 2015/2.

World Bank, 2013, "Beyond the Annual Budget: Global Experience with Medium-Term Expenditure Frameworks," World Bank, Washington, DC. 
Annex 1. Names of the Macro-Fiscal “Departments" of MoFs

MoF "department" that performs the most macro-fiscal
functions ${ }^{26}$

\begin{tabular}{l|l}
\hline Eritrea (ERI) & Fiscal Planning Division \\
\hline Ethiopia (ETH) & Fiscal Policy Department \\
\hline Kenya (KEN) & Macro and Fiscal Affairs Department \\
\hline Lesotho (LSO) & Department of Macroeconomic Policy and Management \\
\hline Madagascar (MDG) & Service du Cadrage Macro-Economique \\
\hline Malawi (MWI) & Macroeconomic policy section (within Economic Affairs Department) \\
\hline Mauritius (MUS) & Macro-Fiscal Framework and Fiscal Risks Unit \\
\hline $\begin{array}{l}\text { Mozambique } \\
\text { (MOZ) }\end{array}$ & Economic and Financing Study Unit \\
\hline Namibia (NAM) & Economic Policy Advisory Services \\
\hline Rwanda (RWA) & Macroeconomic Policy Division (of the Office of Chief Economist--OFE) \\
\hline Seychelles (SYC) & Macroeconomic Forecasting \& Analysis Branch \\
\hline $\begin{array}{l}\text { Tanzania (TZA) } \\
\text { (mainland) }\end{array}$ & Policy Analysis Department \\
\hline Uganda (UGA) & Macroeconomic Policy Department \\
\hline Zambia (ZMB) & Economic Management Department \\
\hline Zanzibar (ZNZ) & Department of Fiscal and Financial Policies \\
\hline Zimbabwe (ZWE) & Fiscal Policy and Advisory Services Department \\
\hline
\end{tabular}

\footnotetext{
${ }^{26}$ In January 2018, in eight countries, the listed "department" performed most macro-fiscal functions. At the time of the survey, in four countries, the MFD's macro-fiscal functions were shared with those performed by a planning or economy ministry. However, in early 2019, Madagascar merged the Ministry of Economy and Planning with the Ministry of Finance. In contrast, in Malawi, in June 2020, the Economic and Planning functions were formally separated from the MoF.
} 


\section{ANNEX 2. Fiscal RuLES AND FisCAL FrameWORKS}

A fiscal rule is a long-lasting constraint on fiscal policy, exercised by placing numerical limits on budgetary aggregates. When a fiscal rule is in place, medium-term fiscal projections prepared by the MFD should be within the boundaries dictated by the rule.

Currency unions often have supranational fiscal rules that constrain fiscal aggregates of each member country. A major objective is to prevent one member-country from adopting profligate fiscal policies that undermine the stability of the exchange rate arrangement. For this reason, 14 francophone countries in west and central Africa have adopted extensive fiscal rules to contribute to the stability of the CFA franc. In the western zone, "first tier" fiscal rules include those on gross debt (70 percent of GDP) and the budget balance including grants (3 percent of GDP).

The six countries of the East African Community (EAC), Burundi, Kenya, Rwanda, South Sudan, Tanzania and Uganda, also have supranational fiscal rules in the form of convergence criteria towards a proposed currency union, notably a ceiling of 50 percent of GDP for gross public debt in net present value (NPV) terms and a budget deficit rule of 3 percent of GDP (the deficit includes grants). These targets were originally planned to become binding in 2021. In all four EAC countries in our sample, none of them had complied with the fiscal deficit convergence criterion in 2017 and 2018.

Fiscal rules differ from medium-term fiscal targets. Following the definition of Lledó et al. (2017), fiscal rules are numerical targets that are binding for at least three years and have a legislative basis, meaning that they are approved by Parliament. Fiscal targets are embedded in MTFFs: the main medium-term targets are those relating to total expenditure, the fiscal deficit, and public debt. Medium-term fiscal targets are not considered to be fiscal rules if they are changed annually or every two-three years.

In 2018, only four of the 16 countries' parliaments had approved fiscal rules and incorporated them in legislation:

- Kenya's 2012 Public Financial Management Act (Article 15) ${ }^{27}$ requires that "over the medium term, the national government's borrowings shall be used only for the purpose of financing development expenditure and not for recurrent expenditure."

- Mauritius' 2008 Public Debt Management Law, as amended in 2017 (IMF, 2017), specifies that public debt shall not exceed 60 percent of GDP by FY2020/21.

- $\quad$ Mozambique's parliament approved fiscal targets of its Five-year Plan for 2015-19. Based on the above criteria, the Plan's target for the fiscal deficit excluding grants ("less

\footnotetext{
${ }^{27}$ Article 15 also contains a "second tier" fiscal rule: at least 30 percent of total expenditure will be devoted to development. As with the "golden rule" this fiscal rule applies "over the medium term."
} 
than 22 percent of GDP" by 2019) and for a revenue/GDP ratio of "32.5 percent of GDP by $2019 "$ are considered to be fiscal rules of limited duration. ${ }^{28}$

Uganda's Charter of Fiscal Responsibility 2016 specified quantitative targets for critical fiscal aggregates over four years. In approving the Charter for 2016/17-2020/21, Parliament endorsed two targets: (1) the fiscal balance (including grants) is to be reduced to no greater than 3 percent of GDP by FY2020/21; and (2) public debt in NPV terms is to be maintained below 50 percent of GDP. Since Parliament, at the beginning of its 4-year mandate, approved the Charter inclusive of numerical rules, Uganda's targets are considered to be fiscal rules with a four-year duration.

In contrast to Kenya and Uganda, the Parliaments of Rwanda and Tanzania had not (in 2018) approved fiscal rules or targets consistent with the Monetary Union Protocol. Although the latter two countries' parliaments review medium-term budget frameworks and/or policy statements, there are few constraints to prevent modifications in the medium-term fiscal objectives in a subsequent year. And even though Kenya has established a "golden rule" in law, it applies over the medium-term, which is not defined in law. ${ }^{29}$ If the Government chooses to deviate from the principles of prudent fiscal management, the budget system laws require the Minister of Finance to explain these deviations in the subsequent year's MTFF. In summary, the legal framework does not prevent the Government from changing its medium-term fiscal strategy each year.

The Governments of Namibia and Seychelles_have established medium-term fiscal objectives for the overall fiscal deficit ("less than 3 percent of GDP"-Namibia) and/or debt ("less than 35 percent of GDP"—Namibia; "less than 50 percent of GDP by 2020/21"—Seychelles). Since these targets have not been formally approved by Parliament-and could be modified by the Government-they are not considered to be fiscal rules.

Fiscal rules have not been adopted in any of the other eight countries of our sample. Lesotho's currency (like that of Namibia) is in the Common Monetary Area with a fixed peg to South Africa's Rand. However, unlike the planned EAC Monetary Union for the six east/central African countries, there are no fiscal convergence criteria applying to each country; medium-term fiscal objectives are unconstrained.

When medium-term fiscal deficit targets frequently change, the MTFF's credibility is undermined. For Kenya, for example, Last et al (2016), observed that "total expenditure in an average year has been revised up by more than 9 percent on average over the last decade, bringing into question the credibility of the MTFF. The upward drift in the fiscal deficit would suggest that fiscal principles are not binding constraints." For Tanzania, Lawson et al (2017) point to the lack of credibility of the annual budget.

\footnotetext{
${ }^{28}$ For details on the targets see Quadro 6, Boletim da República, I Série Número 29 (www.mef.mz). In the base year (2014), the fiscal deficit was 22.7 percent of GDP and the revenue/GDP ratio was 27.5 percent.

${ }^{29}$ There is also a problem of defining "development expenditure." Partly because of the difficulties of defining "investment expenditure," in 2009 Germany changed its Constitutional "golden rule" to an "overall balance" fiscal rule. Kenya faces similar difficulties to unambiguously define "recurrent" and "developing" expenditures.
} 


\section{Annex 3. Medium Term Forecast Performance Analysis}

Figure A1: Average Error of Medium-Term Non-Grants Revenue Forecast (2012/13-2018/19, percent of GDP)

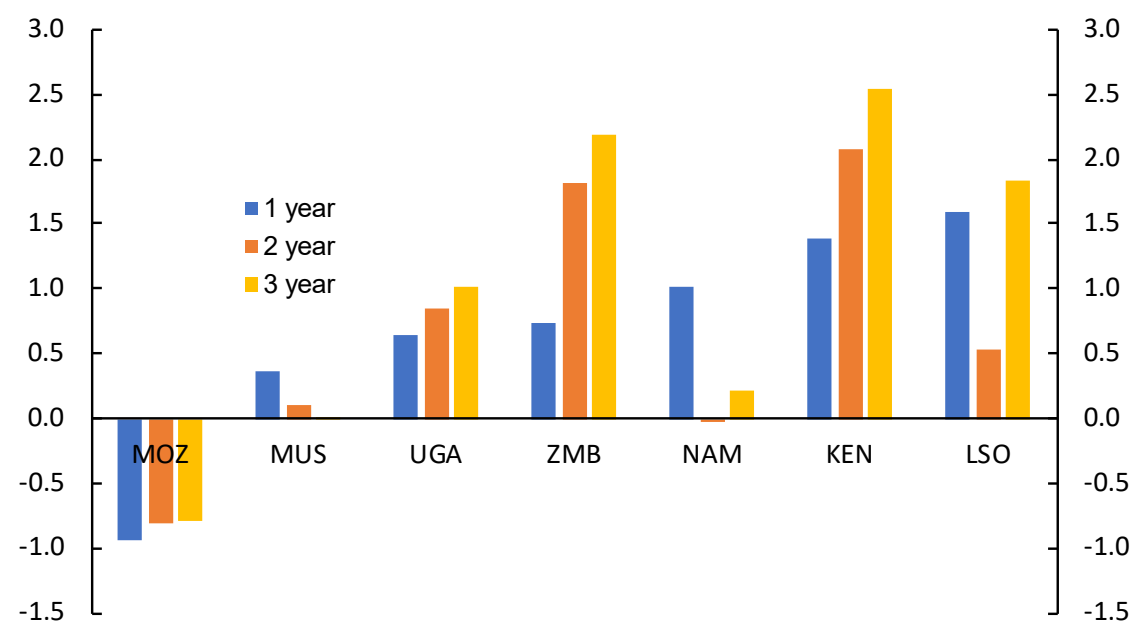

Source: Authors' database constructed from official budget or budget framework documents in each country.

Note: 2013-18 calendar years were used for Mauritius, Zimbabwe, and Zambia. More limited samples were used for Mozambique (2013-2017), Lesotho and Namibia (2012/13-2017/18). Grants are included in the estimates for Zimbabwe.

Figure A2: Average Absolute Error of Medium-Term Non-Grants Revenue Forecast (2012/13-2018/19, percent of GDP)

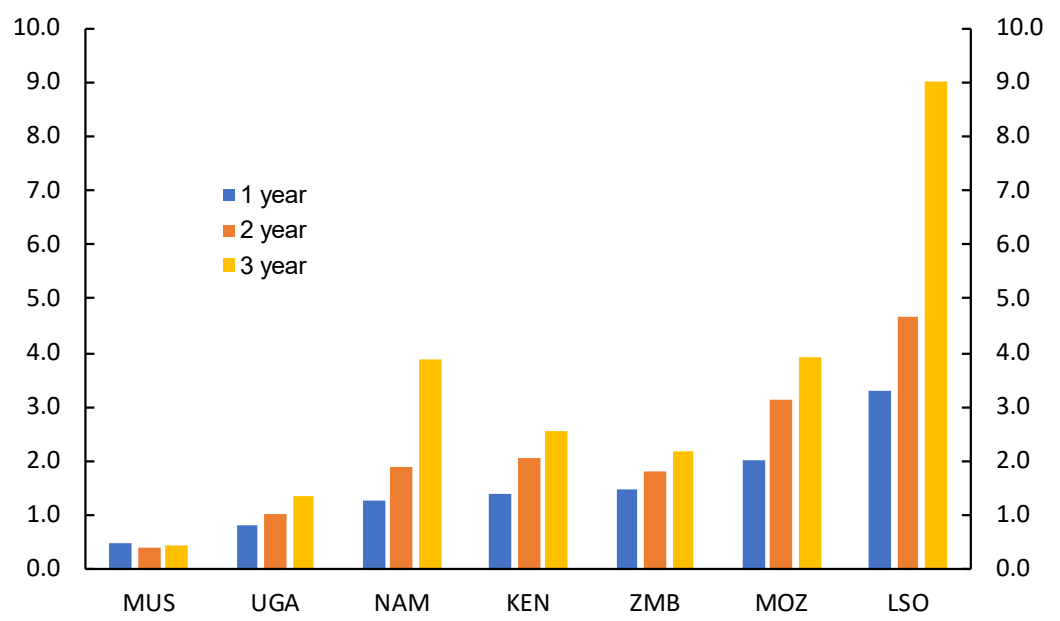

Source: Authors' database constructed from official budget or budget framework documents in each country.

Note: 2013-2018 calendar years were used for Mauritius, Zimbabwe, and Zambia. More limited samples were used for Mozambique (2013-2017), Lesotho and Namibia (2012/13-2017/18). Grants are included in the estimates for Zimbabwe. 
Figure A3. Average Error of Medium-Term Nominal GDP Growth Forecasts (2012/13-2018/19, percent)

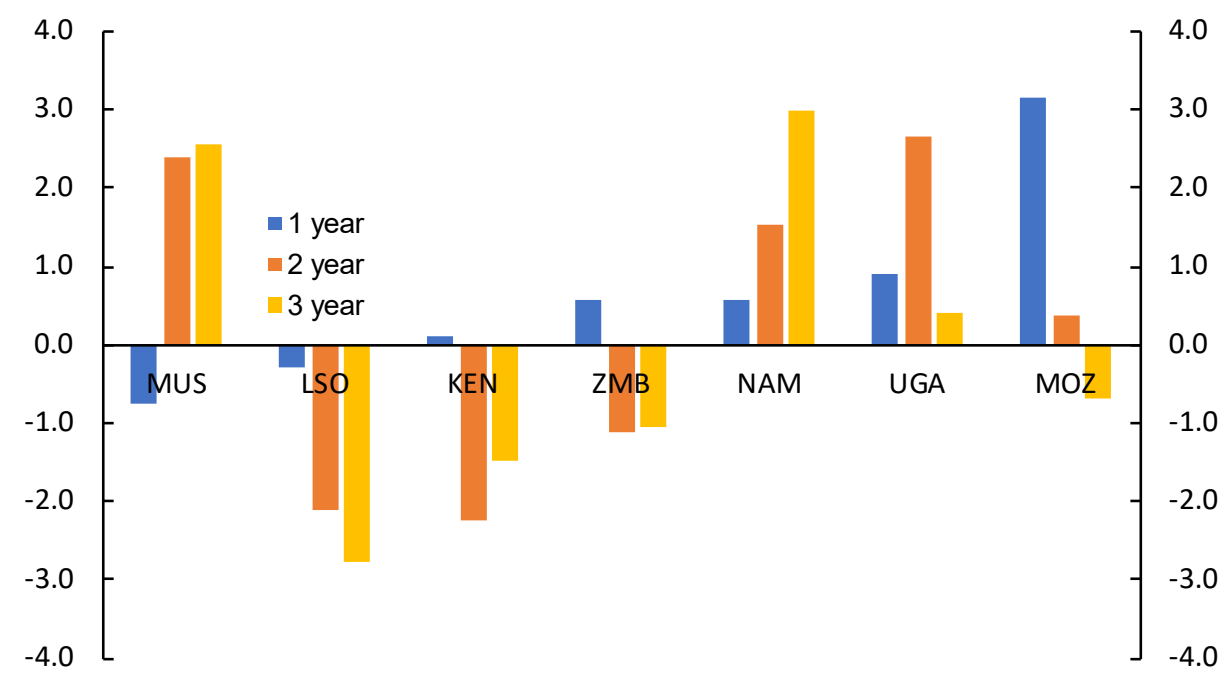

Source: Authors' database constructed from official budget or budget framework documents in each country.

Note: 2013-18 calendar years were used for Mauritius, Zimbabwe, Madagascar, and Zambia. Data for Uganda also includes 2018/19. A more limited samples was used for Zimbabwe (2013-2017). Corrections for some historical forecasts were required due to rebasing in Zimbabwe (2017), Kenya (2014), and Seychelles (2014).

Figure A4: Average Absolute Error of Medium-Term Nominal GDP Growth Forecasts (2012/13-2017/18, percent)

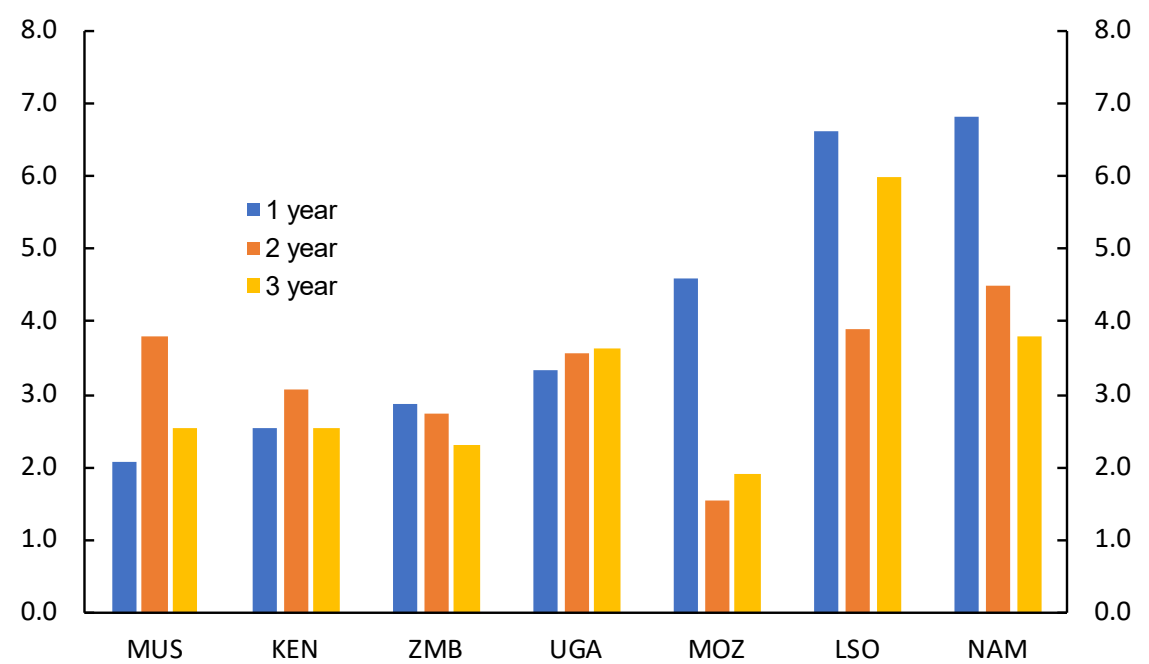

Source: Authors' database constructed from official budget or budget framework documents in each country.

Note: 2013-18 calendar years were used for Mauritius, Zimbabwe, Madagascar, and Zambia. Data for Uganda also includes 2018/19. A more limited samples was used for Zimbabwe (2013-17). Corrections for some historical forecasts were required due to rebasing in Zimbabwe (2017), Kenya (2014), and Seychelles (2014). 
Figure A5: Average Error of Medium-Term Real GDP Growth Forecasts (2012/13-2017/18, percent)

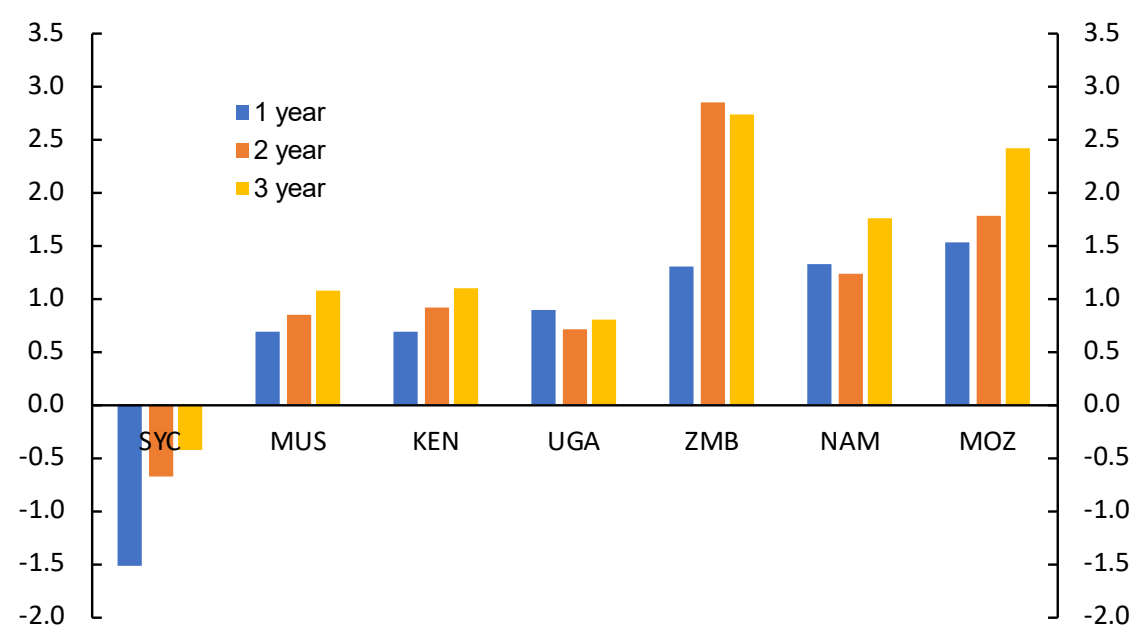

Source: Authors' database constructed from official budget or budget framework documents in each country.

Note: 2013-18 calendar years were used for Mauritius, Zimbabwe, Madagascar, and Zambia.

\section{Figure A6: Average Error of Medium-Term Real GDP Growth Forecasts}

(2012/13-2017/18, percent)

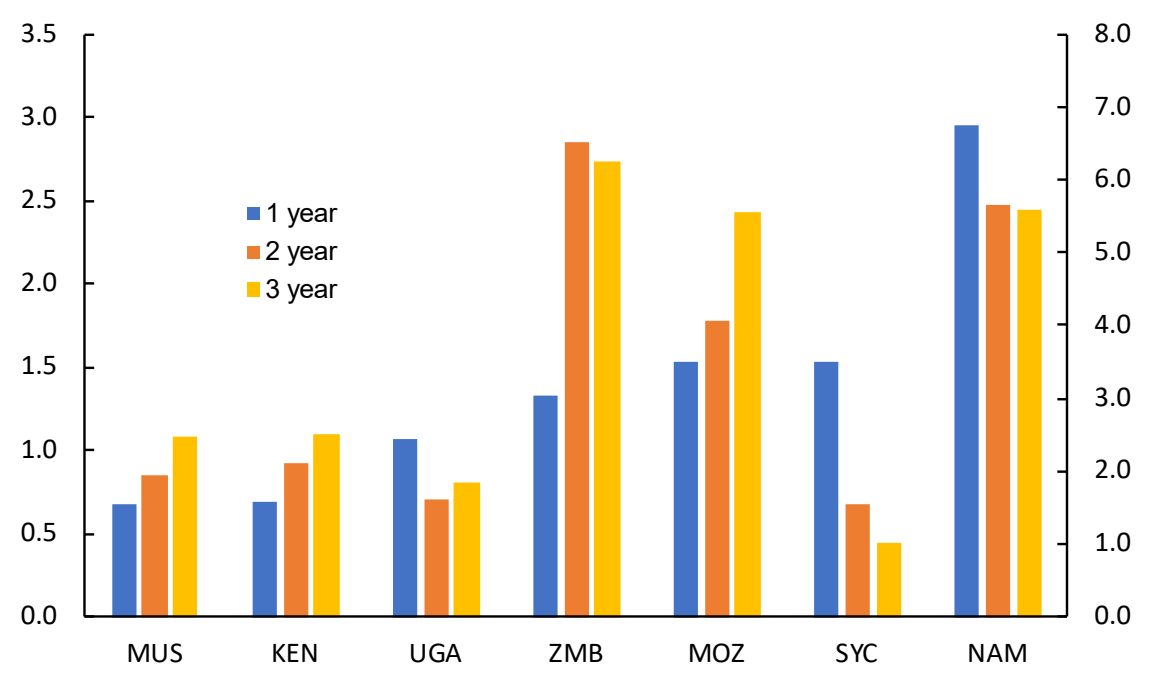

Source: Authors' database constructed from official budget or budget framework documents in each country.

Note: 2013-18 calendar years were used for Mauritius, Zimbabwe, Madagascar, and Zambia. 


\section{Annex 4. Notes on the Database prepared from this Paper}

As noted in the Introduction, data for this study was provided by country delegates to a regional conference on the macro-fiscal function, held in January 2018. In many of the 16 countries, the survey was completed in full. In some cases, there were gaps. These are noted in the figures and tables.

Since the January 2018 cut-off date for the information in the database, some changes have occurred. For example, in mid-2020, Tanzania's Policy Analysis Department had 54 professionals (not 61, as in our database), including four assistant commissioners and a commissioner still to be appointed.

Specific comments on some figures are as follows:

- In Figure 2, staff positions, not actual staff, are shown. In Seychelles, for example, four staff positions in the Macroeconomic Forecasting and Analysis Division were not filled in early 2018. Whereas there were 10 staff positions, Figure 2 shows six staff.

- In Figures 6 and 7, 2013-18 calendar years were used for Mauritius, Zimbabwe, Madagascar, and Zambia. More limited samples were used for Mozambique (2013-17), Zimbabwe (2013-17), Tanzania, Lesotho, Namibia, Seychelles, Malawi, and Ethiopia (2012/13-2017/18), and Rwanda (2012/13-2016/17). Grants are included in the estimates for Zimbabwe.

- In Figures 8 and 9, 2013-2018 calendar years were used for Mauritius, Zimbabwe, Madagascar, and Zambia. Data for Uganda also includes 2018/19. A more limited samples was used for Zimbabwe (2013-2017). Corrections for some historical forecasts were required due to rebasing in Zimbabwe (2017), Kenya (2014), Tanzania (2012), and Seychelles (2014).

- In Figures 10 and 11, 2013-2018 calendar years were used for Mauritius, Zimbabwe, Madagascar, and Zambia. A more limited sample was used for Tanzania (2013-17).

Questions on the database can be directed to the authors, who take full responsibility for the integrity of the data, the figures, tables and analysis (regressions, etc.). 


\section{AnNex 5. Kenya's Statement of Fiscal Risks ${ }^{30}$}

Kenya's 2012 PFM Act requires the preparation of a Statement of Fiscal Risks. The 2018 Budget Policy Statement included a 16-page annex describing the following risks:

Risks in Changes in Macroeconomic Assumptions notably the budgetary risks of: (a) lower real GDP growth; (b) inflation instability; (c) exchange rate volatility; and (d) volatility of commodity prices on imports. The section included a table on Fiscal Sensitivity to Key Macroeconomic Variables, 2018/19.

Assessment of Past Forecast Accuracy. This section included a table on Deviations in Macroeconomic and Fiscal Aggregates of projected and outcome data.

\section{Specific Fiscal Risks}

- Sustainability of Public Debt. The analysis shows that Kenya's debt is sustainable.

- State Corporations/State Owned Enterprises (SOEs). Description of actions the Government has taken to strengthen corporate governance, including issuing a Code of Conduct and operationalizing audit committees. Also:

- Borrowing by State Corporations. State Corporations with strong balance sheets can contract debts only with relevant approvals from the line Ministry and the National Treasury to finance viable projects.

- On-lending to State Corporations. The Government may on-lend concessional loans to State Corporations implementing strategic infrastructure projects.

- Unfunded Pension Liabilities. Unfunded pension arising from early retirement ages is a fiscal risk. The projected pension liabilities have yet to be quantified.

- Public Private Partnership Projects. Past PPP projects and planned infrastructure PPPs in various sectors of the economy are reviewed.

- Natural Disasters. The budget provides a contingency fund to cushion these risks. The impact of unforeseen events could be of greater magnitude than the provision.

- Climate changes. These may adversely impact tax bases and spending programs. Fiscal instruments to limit the damage include disaster relief spending and flood insurance payouts.

- Acts of Terrorism. Fiscal costs include: declines in tax revenue and increased government spending on security and counter-terrorism.

- Technological Disaster. The reliance on IT systems exposes the Government to a range of risks such as cybercrime, and data corruption or loss.

- Liabilities of the financial sector via systemically important banks. Fiscal risks are inherent in the mandate the Kenya Deposit Insurance Corporation.

- Devolved system of Government. Major risks have emerged from Kenya's fiscal decentralization. The statement summarizes County Governments' main fiscal risks and proposed mitigation measures.

\footnotetext{
30 Source: Annex 2, 2018 Budget Policy Statement, National Treasury, Kenya.
} 